\title{
Correspondência de Adolpho Lutz Cartas selecionadas
}

\author{
Cartas em alemão transcritas e traduzidas por: \\ Johann Becker \\ Löre Paztmann \\ Talita Gross
}


O Brazil-Medico

Revista Semanal de Medicina e Cirurgia

Publicada sob a direção do

Dr. Azevedo Sodré

Professor da Faculdade de Medicina do Rio de Janeiro

Rua do Rosário, 100

Rio de Janeiro

Rio de Janeiro, 21 de setembro de 1904

Prez coll $^{\mathrm{a}}$ e $\mathrm{am}^{\circ}$ dr. A. Lutz

Cordiais saudações.

O dr. Miguel Bombarda, secretário geral do XVI Congresso Internacional de Medicina e Cirurgia a reunir-se em Lisboa em abril de 1906, escreveu-me incumbindo-me de constituir um comitê que promovesse a representação do Brasil naquele certame científico. Pediu-me, outrossim, que escolhesse os profissionais brasileiros nos casos de relatarem questões perante o congresso e que distribuísse por eles um dos temas constantes dos boletins mensais publicados ou de livre escolha minha. Em sua última carta disse-me que lhe tinha escrito diretamente, solicitando a sua adesão e propondo-lhe escrever um relatório sobre: "etiologia e profilaxia da febre amarela". Carta em idênticos termos foi endereçada ao dr. F. Fajardo, que já respondeu declarando aceitar a incumbência e prometendo enviar relatório sobre o referido assunto.

Venho hoje reiterar o convite que lhe foi feito pelo dr. Bombarda; não podemos dispensar o seu valioso concurso, e para garantir o êxito da representação científica do Brasil naquele certame julgo imprescindível a sua colaboração.

O tema que lhe foi oferecido pelo dr. Bombarda já tem um relator (médico português) e vai ser também tratado pelo dr. Fajardo. Creio que seria preferível encarregar-se V. de um outro tema a sua escolha entre os que figuram nas relações enviadas ou mesmo independentes delas em que se the afigure do interesse.

Eu estimaria que V. relatasse um assunto de patologia indígena, por exemplo: ancilostomíase, beribéri, lepra etc. O dr. Sanarelli propôs-se a relatar o seguinte tema: "Do hóspede intermediário na febre amarela". Penso que seria altamente vantajoso que um dos médicos brasileiros, que aceitam a transmissão culicidiana, se encarregasse também de sub-relatar o mesmo assunto. Quererá V. se incumbir disto?

Aguardo ansioso sua resposta, pedindo-lhe não a demore muito, a fim de eu poder responder ao Bombarda.

Desejando-lhe saúde e todas as felicidades.

Subscrevo-me com a mais cordial simpatia e distinta consideração Seu coll ${ }^{\mathrm{a}} \mathrm{am}^{\mathrm{o}}$ e $\mathrm{adm}^{\text {or }}$

Azevedo Sodré*

*Antônio Augusto de Azevedo Sodré nasceu no Rio de Janeiro em 13.2.1864 e faleceu em Petrópolis, em 3.3.1929. Doutorou-se em medicina em 1885 com tese sobre métodos de tratamento da sífilis. Em 1894, conquistou a cátedra de patologia interna da Faculdade de Medicina do Rio de Janeiro, de que foi diretor em 1911-12. Foi também professor de medicina legal da Faculdade de Direito, presidente da Academia Nacional de Medicina, prefeito do Distrito Federal e deputado federal pelo estado do Rio de Janeiro. Publicou vários livros e artigos sobre política sanitária e educação, e sobre enfermidades como cólera, doenças intestinais, tuberculose, malária, ancilostomíase e, especialmente, febre amarela, que estudou em colaboração com Miguel Couto. Azevedo Sodré teve papel destacado na vida médica brasileira. Foi um dos fundadores da Sociedade de Medicina e Cirurgia do Rio de Janeiro, criou a Sociedade dos Internos dos Hospitais e fundou O Brazil-Medico, Revista Semanal de Medicina e Cirurgia, durante muitos anos o principal periódico médico do país. (N. do ed.) 
EKALIL-MLUILU Tis de Gaveirs, $2 / 2$ etembtro 1908 pa. fravkeo Sodre

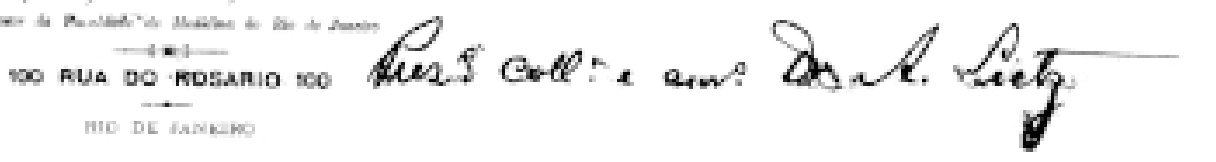

bosdines vardoegues.

O A Ruigual Bonalimila, de

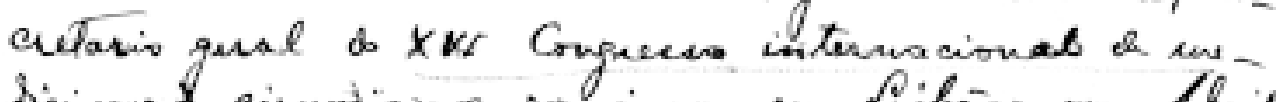

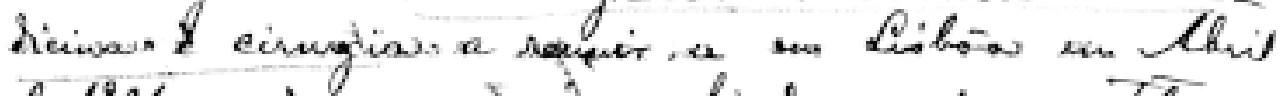

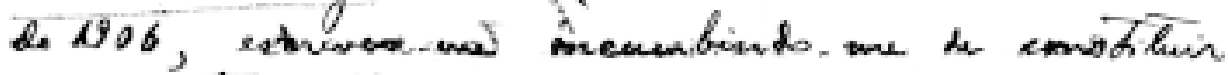

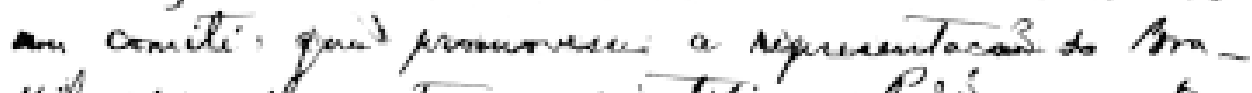

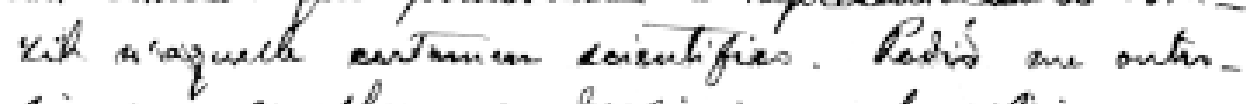

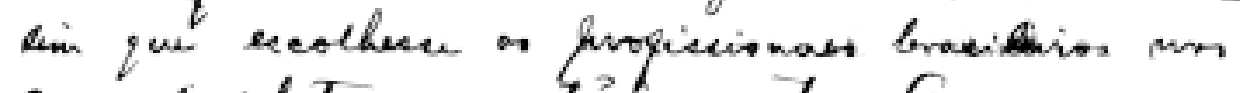

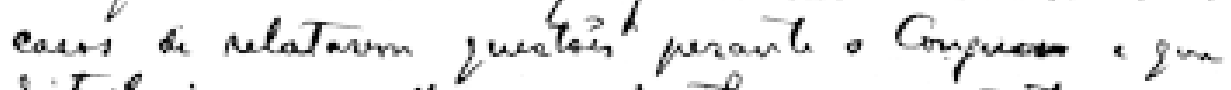
ditribuice por ellos com on themas covitants on

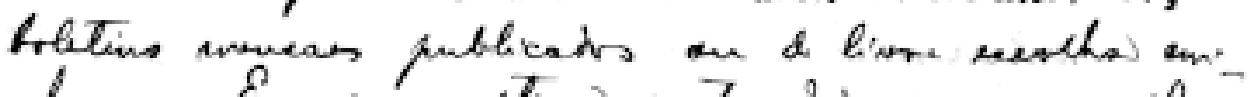

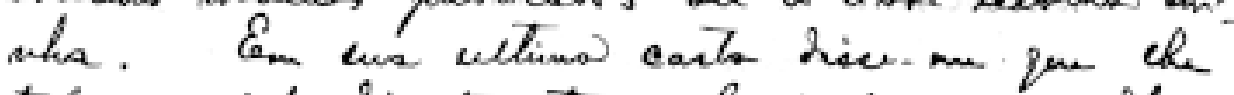

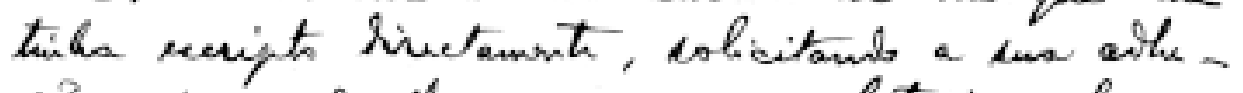

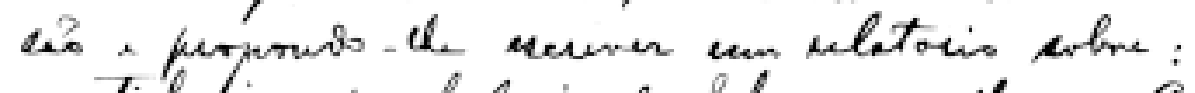

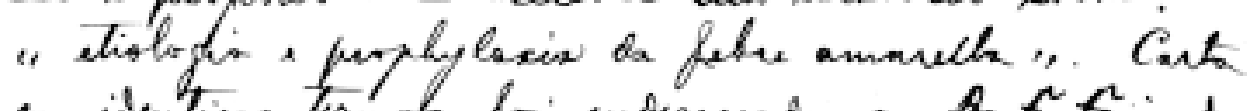

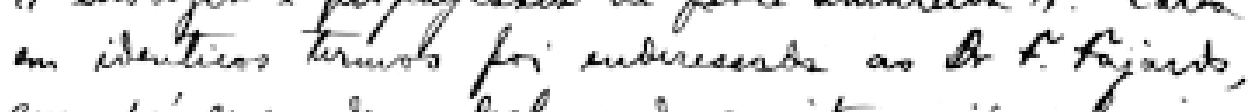

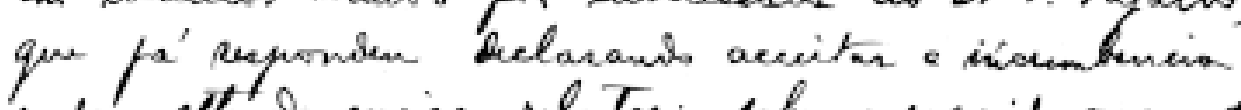

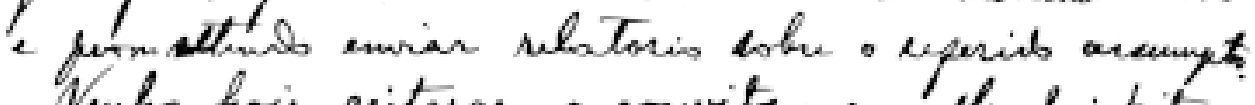

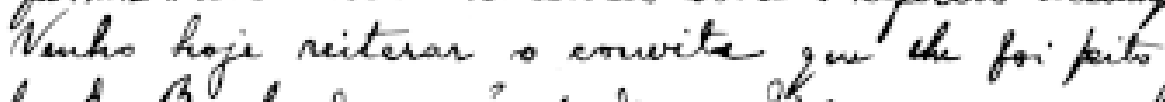

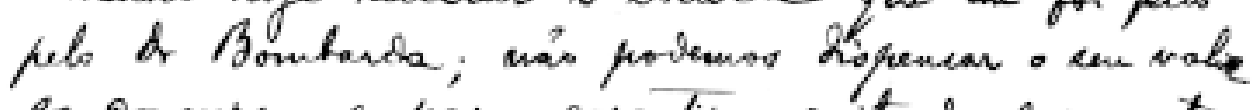
es oncurse, e para garantir. exito da repuents.

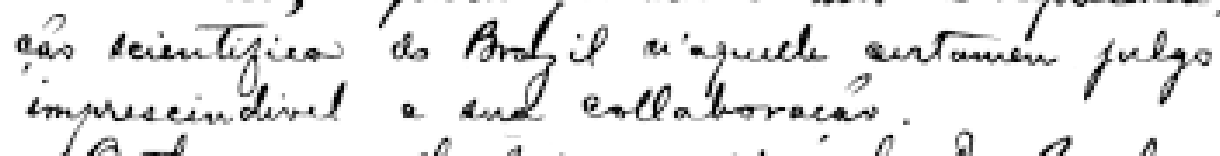

O thens gue the foi offereids pelo or Bowboct

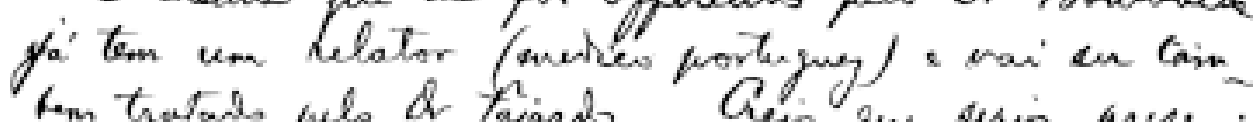

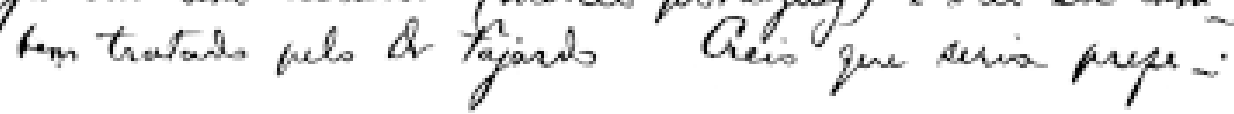

vol. 10(1):287-409, jan.-abr. 2003

315 


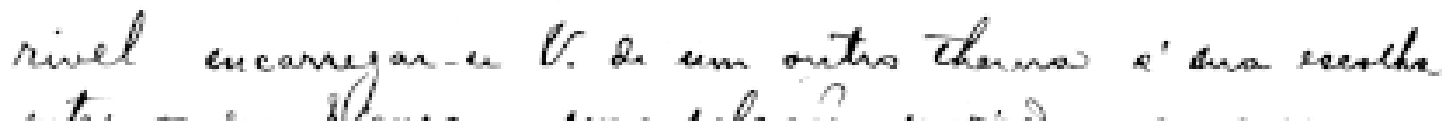

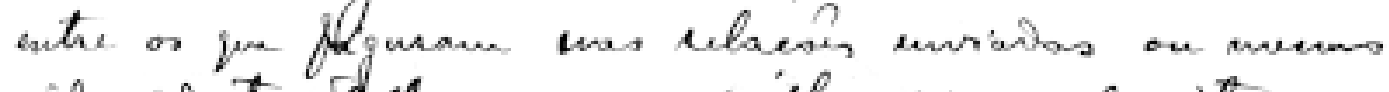

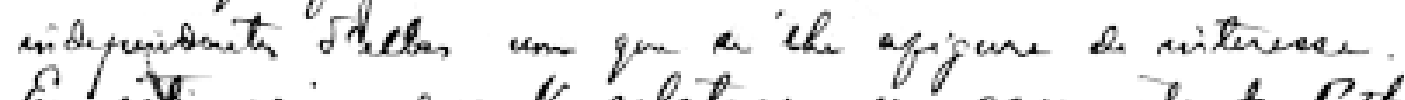

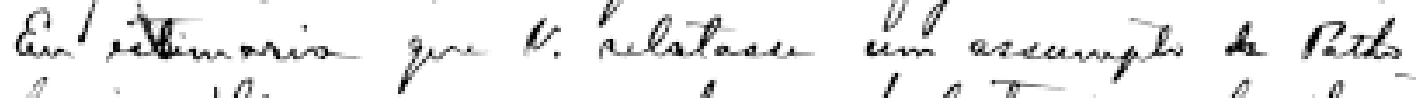

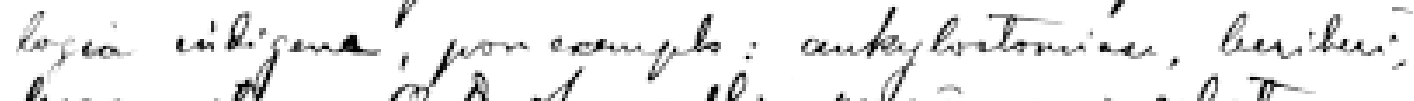

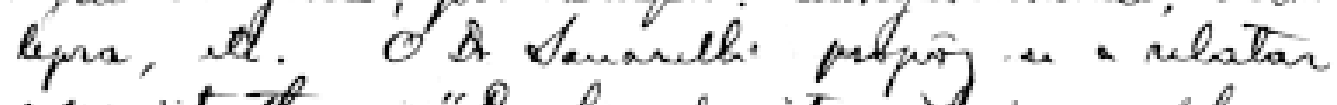

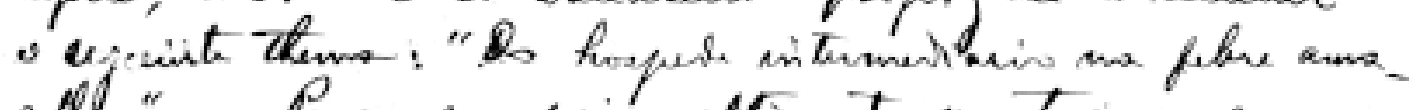
relll." Panso que teria altainnit mantajoce ine un

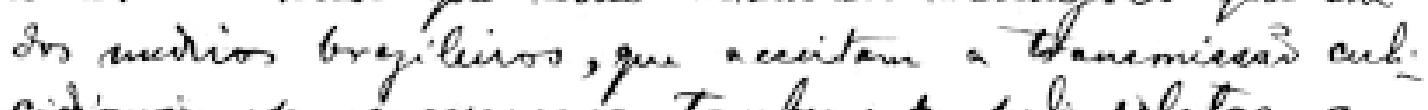
cidianas, he inearryaca tambur a dulinulatar o

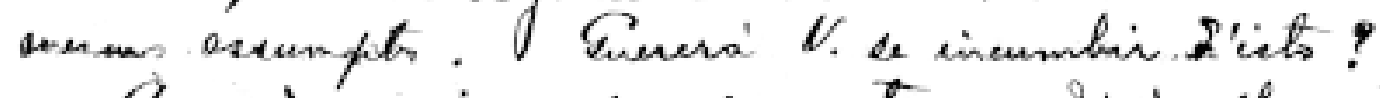

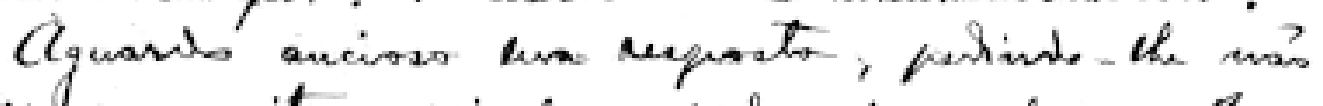

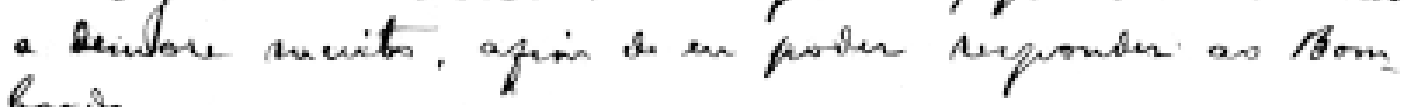
bariba.

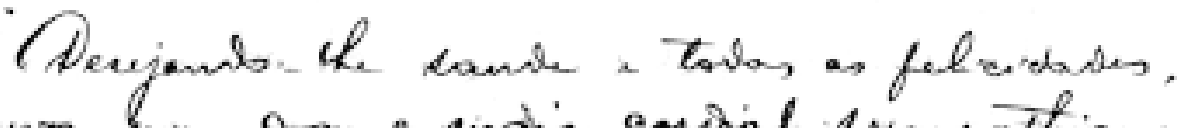

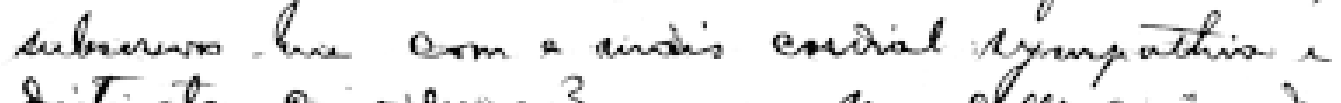

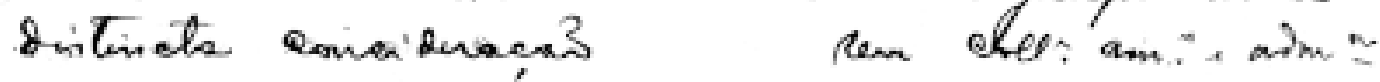

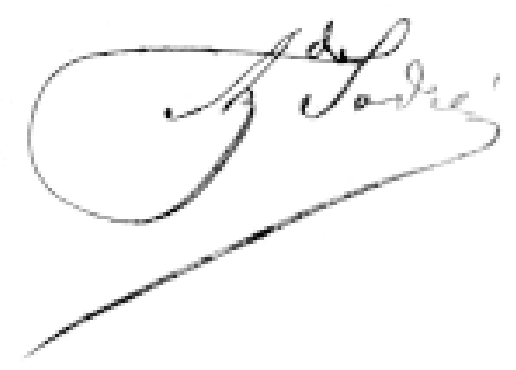

316

História, Ciências, Saúde — Manguinhos, Rio de Janeiro 
$\mathrm{Am}^{\circ}$ colega dr. Lutz

Já deve ter chegado ao seu poder o último número do Brazil; tem algumas incorreções o seu artigo nele publicado e espero os corrigidos para serem aplicados à tiragem à parte.

$\mathrm{O}$ dr. Peixoto, de Campos, foi eleito deputado geral. Ele já está curado daquela lesão da barba. Felizmente não foi preciso operação. Há dias, estando comigo, pediume que o recomendasse.

Não se sabe ainda sobre quem recairá a escolha para a cadeira de clínica, vaga por morte do Torres Homem. Talvez o governo mande a concurso a mesma, o que é mais acertado e legal. Assim qualquer dos pretendentes pode se apresentar e conquistá-la pelos meios mais lícitos.

O Brazil-Medico vai publicar uma revista mensal, suplementar, a que servirá para os trabalhos originais.

Minha família muito se recomenda e eu particularmente, desejando-lhe saúde e prosperidades.

Rio, 19.11.1887

O seu colega e amigo

Azevedo Lima*

*José Jerônimo de Azevedo Lima (1850-1912) foi um dos fundadores da Liga Brasileira contra a Tuberculose. De 1879 a 1900, dirigiu o Hospital dos Lázaros, no Rio de Janeiro. (N. do ed.) 
Amigo dr. Lutz

De posse da sua última carta, procurei imediatamente o dr. Azevedo Sodré, redator de Brazil-Medico, que infelizmente se achava doente e com quem por isso não pude logo falar a respeito do seu trabalho e das objeções que o amigo expunha quanto às condições de publicação do mesmo. Por vezes tenho ido procurá-lo, mas ele não tem ainda vindo à cidade por doente.

Nesse ínterim recebo hoje um número do Brazil-Medico em que já vem publicado o primeiro artigo do seu trabalho; pois que eu já lhe tinha fornecido algumas tiras da tradução. Não darei, porém, outras, enquanto a coisa não estiver decidida quanto ao preço de tiragem dos seus exemplares. Parece-me, entretanto, que não ficará tão caro como na sua última carta o amigo supõe; seja porém como for, entendo que se deve primeiro assentar num cálculo mais ou menos aproximado, o que ainda não fiz porque a pessoa com quem me devo entender é, como disse, o dr. Azevedo Sodré, que não tem vindo à cidade.

Diga-me como se vai dando em S. Paulo, e se pretende ficar ali.

Nós, eu e a família, temos passado bem e muito nos recomendamos, desejando-lhe saúde. Disponha do

Seu $\mathrm{am}^{\circ}$, colega e obro

\section{Azevedo Lima}

NB. Desejava ler o Bidenkap e não o tenho encontrado aqui.

Recebi e agradeço-lhe muito o Ermengem cuja oferta me penhorou muito.*

\section{Do Lima}

José Jerônimo de Azevedo Lima referia-se, provavelmente, a Johan Lauritz Bidenkap, autor de Aperçu des différentes méthodes de traitement employées à l'hôpital de l'Université de Christiania contre la syphilis constituionnelle (Christiania, Impr. chez H. J. Jensen, 1863), e ao Manuel technique de microbiologie (Paris, Steinheil, 1887) de Emile P. van Ermengem. Este último autor publicara também Recherches sur le microbe du choléra asiatique; rapport présenté à M. le Ministre de l'intérieur, le 3 novembre 1884 (Paris, Carré, 1885), e publicaria, em 1897, um livro sobre intoxicações alimentares. Tudo indica que a carta de Azevedo Lima foi escrita no segundo semestre de 1888 , depois que saiu em O Brazil-Medico, Revista Semanal de Medicina e Cirurgia, periódico editado por Azevedo Sodré, o primeiro artigo da série que reproduziria em português 'Ankylostoma duodenal e Ankylostomiase', publicado por Lutz na Alemanha. (N. do ed.) 
Amigo dr. Lutz

Rio de Janeiro, 26 de novembro de 1894

Antes do mais faço os meus melhores votos pela sua saúde e de sua sra., a quem apresento os meus respeitos.

Há tanto tempo que não tenho notícias suas que espero m’as dará, dizendo-me como tem passado e como vai se dando aí em S. Paulo.

Sinto que o meu amigo não tenha querido viver em esta cidade, conquanto saiba aqui que os seus méritos têm sido justamente apreciados aí, não só pela classe médica, como pelo governo que o incumbiu de uma repartição oficial. O pouco tempo que tive a fortuna de aqui vivermos no Rio em conversa sobre cursos de medicina, incutiume o gosto por certas investigações e desde então comecei a me convencer de que sem um laboratório anatomopatológico, montado em regra no Hospital de Lázaros, nada poderíamos fazer de prático naquele estabelecimento. Havia e há tantas lacunas no estudo da lepra que só com o concurso dessa ciência nova e já tão fértil em resultados práticos - a bacteriologia - algumas coisas poderíamos fazer. Propus e foi criado, portanto, um instituto para esses estudos à frente do qual se acha o dr. Havelburg, que vai mostrando aptidão para o assunto e muita dedicação. O instituto está provido de todo o material necessário para estudos de bacteriologia e teremos a maior satisfação em ver o meu amigo aqui. Se quiser nos honrar com sua visita, sabe que tem aqui uma casa às suas ordens para si e para sua sra., e no instituto terá todas as regalias, pois foi o seu amor por esses trabalhos que me sugestionou, levando-me a propor a criação dele.

Acabo de receber uma carta do dr. Hilário de Gouvêa, que está em Paris, pedindome que lhe pergunte se não recebeu uma carta dele relativa a umas informações que ele quer sobre distomíase. Desejo responder-lhe nesse sentido e por isso lhe peço a fineza de me informar se recebeu ou não essa carta, cuja resposta ele precisa com brevidade, porque tem de escrever uma tese para clinicar em Paris e não pode prescindir do concurso do meu amigo.

Eu continuo a morar na mesma casa, rua de S. Cristóvão, 197, com escritório na rua da Quitanda, 60. Já tenho cinco filhos. Sua sra., como passa? Apresente os meus cumprimentos a esta e disponha do

Seu amigo velho e obrigado

Azevedo Lima 


\section{Amigo dr. Lutz}

Rio de Janeiro, 9 de abril de 1895

Recebi sua carta e respondo já porque parto no dia 11 deste para a Europa. Vou demorar-me em Paris, mas, se o estado de minha mulher melhorar, irei à Alemanha e à Inglaterra e nesse caso aceito as recomendações que me ofereceu, e nesse caso lhe mandarei de Paris o endereço para me remeter as cartas.

Quanto aos livros, escreva ao Domingos Joaquim de Azevedo - Hospital dos Lázaros - Rio (conhece-o com certeza) porque agora já não tenho tempo para providenciar.

Também disse a ele que, segundo sua ordem, remeta a quantia de $\mathrm{R} 85 \$ 000$, produto dos livros vendidos - para onde o meu amigo mandar.

O endereço do Peixoto é este:

Dr. Manoel Rodrigues Peixoto

Estação do Ururahy

Campos

Hei de lhe escrever da Europa.

Apresente meus cumprimentos a sua Exma. sra., um beijo a sua filhinha e creia no Seu $\mathrm{am}^{\circ}$ grato

Azevedo Lima

Paris, 24 de junho de 1895

Meu caro amigo, dr. Lutz

Quando lhe escrevi pela última vez comuniquei-lhe que, por (problemas) de saúde de minha sra., vinha à Europa.

Aqui chegando, depois de uma viagem penosa, tendo isto forçado a me demorar uns dias em Lisboa, outros em Madri, fui consultar o dr. Pinard, especialista de moléstias de sras., aqui muito reputado, e ele pensou logo na necessidade de uma operação, mas pediu-me uma conferência em outro colega de sua confiança.

Do resultado da conferência ficou assentado que tornava-se urgente a operação, porquanto os [anexos] do útero estavam muito comprometidos e o estado geral da doente não comportava demora. Assim se fez e com a maior felicidade, porque ela agora está em convalescença. Eis por que ainda não lhe dei notícias minhas.

Tencionava dar um passeio mais longo, mas além das saudades dos filhos que deixei, estou vendo um câmbio de boca escancarada contra quem tem de servir-se de moeda estrangeira; por isso em fins de agosto ou começo de setembro devo estar de volta e lá me encontrará, se lá o meu amigo for dar um passeio.

Apresente os meus respeitosos cumprimentos a sua Exma. sra., beije por mim a sua filhinha e disponha de quem é com particular estima

Seu amigo, cort $^{\circ}$ e $\mathrm{mt}^{\circ} \mathrm{ob}^{\circ}$

Azevedo Lima

3 rue Saint Didier 
Rio de Janeiro, 9 de fevereiro de 1896

Meu prezado amigo, dr. Lutz

Tive muito prazer em receber a sua carta de 6 deste mês, que me diz não ter recebido carta minha. Eu, logo que cheguei da Europa, escrevi-lhe, dirigindo a carta para a rua Direita. Quanto aos seus livros, eu os deixei ficar na rua do Ouvidor, em casa de Gomes Brandão, e supunha que eles tinham ido já para o seu poder, quando agora o meu $\mathrm{am}^{\circ}$ me participa que não.

Vou dar as providências a esse respeito e peço me releve a demora que não foi motivada por mim.

Sou-lhe muito grato pelo convite que me faz de eu ir a S. Paulo. Estou de fato desejoso de o ver e, portanto, se nas proximidades do carnaval eu não tiver doente cuja gravidade imponha a minha presença aqui, irei visitá-lo, mas então eu o avisarei pelo telégrafo.

Se, porém, eu tiver motivo que me impeça de ir, ficará a minha visita para outra oportunidade.

Eu tinha ido à Europa por incômodos de minha sra. Felizmente ela veio restabelecida.

Acho muito sensatas as considerações que me faz sobre a nossa classe. Aqui no Rio dá-se o mesmo que me descreve em S. Paulo: em geral antepõem ao interesse científico e à dignidade profissional o interesse pessoal e a exploração de um modo que não condiz com a educação científica. Haja vista a especulação ultimamente feita com relação ao que chamam "Serumterapia da febre amarela". Começaram a dizer que o sérum de convalescente de febre amarela serviria para imunizar os atacados desta moléstia.

Isto simplesmente por ilação, por mera conjectura, e logo depois já o autor da idéia supunha-se com o direito a um prêmio por aquela concepção genial. E o que é mais: o mesmo médico mandou logo telegrafar para a Europa comunicando que ele tinha descoberto tratamento infalível da febre amarela! O dr. Abel Parente! E nunca ele empregou tal sérum.

Minha família passa regularmente. Desejo que sua sra. e filhinha, que eu desejo ver, estejam passando bem.

Repito: se eu puder ir passar lá o carnaval, lhe mandarei um telegrama; no caso contrário, até ocasião oportuna.

Aceite muitas lembranças nossas e creia em quem se subscreve com particular estima

Seu amigo certo e obr ${ }^{\circ}$

Azevedo Lima 
Rio de Janeiro, 9 de março de 1898

Meu caro amigo, dr. Lutz

Tive muita satisfação ao receber a sua carta, a qual não respondi já, porque ainda estava com a esperança de poder realizar a minha visita ao meu amigo ainda neste mês; mas serviço profissional em clientes, que eu não posso confiar a outro, obriga-me a retardar os dias de satisfação que hei de ter ao vê-lo e a sua Exma. sra. e filha, a quem apresento meus respeitosos cumprimentos. Sinto ainda mais não poder ir já a São Paulo, quanto me seria agradável cumprimentar aí o dr. Sanarelli. Sinto que ele não venha ao Rio de Janeiro, onde um não pequeno número de médicos, sem dependências nem ligações suspeitas, teria imenso prazer em lhe proporcionar ensejo para pôr em evidência o valor de seu processo terapêutico, como creio que o fez em São Paulo. Li hoje que ele fez na Sociedade de Medicina uma exposição das experiências em S. Carlos do Pinhal e que o resultado é satisfatório quanto às qualidades profiláticas do seu soro. Oxalá que tais conclusões sejam confirmadas.

Deixei, é verdade, o cargo que há anos exercia no Hospital dos Lázaros. E o motivo foi quererem dar a direção do laboratório de bacteriologia a um sujeito que nunca tinha visto uma preparação microscópica, quando a responsabilidade moral da criação e da manutenção de tal laboratório competia a mim, que não podia admitir que um instituto criado para fins científicos fosse desviado em seus destinos para fins de patronato.

Eis a única razão. O serviço lá está organizado; fácil é agora a continuação.

Cumprimento-o e a sua Exma. sra. e como sempre, subscrevo-me com muita estima Seu $\mathrm{am}^{\circ}$ certo e cort.

Azevedo Lima

\section{Meu caro amº dr. Adolpho Lutz}

Recebi com muito prazer a notícia da sua breve viagem ao Rio. À rua de São Cristóvão, 197 tem uma casa às suas ordens, onde espero ter o prazer de o receber.

São raros os casos de febre amarela. Eu mesmo ainda não vi um só doente na quadra atual.

O seu ajudante pode vir sem receio, porque em Campos não há febre amarela. O que ele lá pode contrair é alguma infecção palustre, mas isso mesmo não é muito freqüente. Mosquitos há de arranjar muitos; cobras, também, mas já com alguma dificuldade.

Tem havido interrupção na Estrada de Ferro Macaé-Campos, mas creio que a linha ficará desimpedida dentro em poucos dias. Mandei-lhe há dias uma remessa de mosquitos, que deve ter chegado ao seu poder há uns oito dias.

O sangue do beribéri é que não posso mandar já, porque o doente que eu estava tratando, mandei para São Domingos e é preciso que eu lá vá para colher uma dose.

Mande-me dizer quando vem e apresente meus respeitos a sua sra. e filha.

Os cumprimentos do

$$
\text { Seu } \mathrm{am}^{\circ} \text { (ilegível) }
$$

\section{Azevedo Lima}


Amigo e mestre

Dr. Lutz

Junto lhe envio um cartão com endereço do lugar onde podem ser vistas as máquinas de escrever, as quais me parecem muito mais perfeitas que as antigas.

Já estou de posse dos $85 \$$ que lhe pertencem e remeterei pelo primeiro portador seguro, ou, se receber aviso seu, pelo correio.

As peças anatômicas irão na mesma oportunidade, bem como os porquinhos* etc.

Seus livros é que ainda não consegui obter.

Queira aceitar os melhores cumprimentos do disc ${ }^{\circ}$ e am $^{\circ}$

F. Fajardo

Rio

8.V.95

Amigo e mestre dr. Lutz

Envio-lhe mais duas preparações de cortes do intestino disentérico: tenho procurado a base das úlceras.

Junto desses folículos fechados, na marca do lápis azul me parece estarem bem evidentes ambas, algumas com vacúolos e granulações miúdas dentro.

Recebi sua última carta e é mais um favor examinar estas preparações e enviar-me sua valiosa opinião incontinênti.

Mande-me dizer se quer eu lhe envie hemotoxilina que não achei no mercado, mas tenho no laboratório em natureza ou em solução que estou usando. Esta está agora em bom ponto para ser usada e eu lhe poderei mandar metade dela, que não é muita, mas posso enviar-lhe prontamente se quiser: eu a preparei em maio deste ano.

Espero sua resposta,

$\mathrm{O} \mathrm{am}^{\circ}$ muito $\mathrm{ad}^{\mathrm{r}}$.

F. Farjardo

Rio

7.XII.95

*Referia-se a porquinhos-da-índia, usados em experiências de laboratório. Francisco de Paula Fajardo Junior nasceu a 8.2.1864, no município de Santa Maria Madalena, estado do Rio de Janeiro, e faleceu aos 42 anos, em 6.11.1906, em conseqüência de um choque anafilático provocado pela inoculação do soro antipestoso de Manguinhos. Mais informações sobre este brilhante clínico, hematologista e bacteriologista encontram-se em 'Adolpho Lutz: um esboço biográfico', neste número da revista. (N. do ed.) 
Rio, 4 de março de 1900

$\mathrm{Am}^{\circ}$ dr. Lutz

Recebi ontem, e examinei, a belíssima preparação da malária que teve a amabilidade de mandar-me.

Tenho-me exercitado bem no método de Ziemann, dado por muitos como o mesmo do Romanovsky, aplicando-o à malária, com o intuito de explorá-lo inteiramente e de modo definitivo com relação ao beribéri, mas nunca obtive preparação tão bela: é um modelo de coloração o preparado que aí me mandou.

Quanto à abundância da forma parasitária já vi um caso assim há dois ou três anos, de acesso pernicioso, comatoso, no qual fiz autopsia com o dr. Miguel Couto.

Estes trabalhos que o sr. tem feito de malária pedem publicidade.

Cumprimentos do disc ${ }^{\circ}$ e $\operatorname{am}^{\circ}$ certo.
A. Fajardo

\section{2, r. do Hospício}

Rio, 28.5 .00

Dr. Lutz

Envio-lhe hoje o que tenho do Rach. Já encomendei repetidamente; porém até hoje nada mais me veio às mãos.

Rogo-lhe o obséquio de mandar-me o quanto antes uma explicação detalhada do seu modo de colorir os parasitos do sangue, pelo método de Romanovsky - é grande favor.

Continuarei a escrever.

$\mathrm{Am}^{\circ}$ e $\mathrm{ad}^{\mathrm{dor}}$

\section{Dr. F. FAJARDO}

CLÍNICA DE MOLÉSTIAS INTERNAS

Consulta das 2 às 4, r. Hospício, 22

Resid. Rua Marquês de Abrantes, 41

$\mathrm{Am}^{\circ}$ dr. Lutz

Aí vão três lâminas com nossa cultura de beribérico, pedindo-lhe para aplicar o método Romanovsky e me dê o resultado ou mande uma preparação.

Ensaiei sem resultado, na malária, as soluções que o sr. teve a bondade de enviarme.

Por que não obtive resultado?

Fixei tanto pelo álcool ab., como pelo álcool e éter, como calor.

Do $\mathrm{am}^{\circ}$ e $\mathrm{ad}^{\mathrm{dor}}$.

F. Fajardo

13.6.00 


\section{DR. F. FAJARDO - RIO DE JANEIRO}

41, r. Marquês de Abrantes

19.10 .00

Amigo dr. Lutz

Mandei-lhe alguma coisa pelo dr. Meyer; outras culturas virão ainda. Quanto ao pessoal que me disse para indagar, eu fui à Escola de Alfort e conversei com o prof. Lignières, mas ele me respondeu: aqui não se tem vontade de ir para o Brasil porque, chega-se lá, está mudado o prefeito e já os contratos nada valem mais e fica-se abandonado. Disse-me ele então que eu lhe dissesse para escrever a ele expondo tudo bem claramente e as garantias.

Levei comigo sua preparação de acesso pernicioso e mostrei-a a Laveran, o qual apreciou-a muito. Ele autorizou-me a dizer-lhe que está pronto a corresponder-se com o sr. e que, desde já, aceitará os mosquitos que eu disse que o sr. colhe e estuda; ele corresponde-se com o mundo todo. O sr. já ensaiou um método novo que ele publicou para coloração dos hematozários? Vi com ele estudos de Ross belíssimos.

Quanto aos meus trabalhos há o seguinte. Li minha contribuição em seção de bacteriologia e parasitas. O dr. Ziemann, que também estava presente, já começou a fazer estudos de contrapesos, mas não se julga ainda habilitado a pronunciar-se. Mostrei preparados do cérebro e um periférico a Laveran, Félix Mesnil (chefe do Laboratório do Instituto Pasteur) e a Lignières. Quanto ao cérebro, a opinião deles é absolutamente a sua, isto é, vê-se claramente o pigmento, porém as formas parasitárias não podem ser garantidas.

Mesmo no sangue periférico em fase de divisão, ou em caso clássico de beribéri, fiz-lhes forte impressão e inclinam-se a ver nele uma forma parasitária. Se eu tivesse podido levar abundantes preparados periféricos, penso que, Laveran pelo menos, se teria pronunciado. Fiquei de mandar preparados periféricos.

A preparação de que lhe falei agora ser-lhe-á mandada qualquer dia. Enfim voltei satisfeito quanto aos meus estudos.

O sr. já leu o livro de Lignières que lhe enviei: foi uma das notas do congresso a cultura do hematozoário da febre do Texas que ele parece ter resolvido definitivamente.

Já lhe tomei muito tempo, paro aqui. Respeitos nossos à [excelentíssima] e a ti abraça o amigo e addor.

F. Fajardo 


\section{SERVIÇO CLÍNICO}

Rio 12.1.01

Amigo dr. Lutz,

Recebi sua carta, que muito lhe agradeço. Mandarei outros exemplares dos mesmos mosquitos para ver se os classifico agora. Estou procurando Anopheles.

O dr. Lutz tem aí peças anatômicas com lesão tuberculosa, do homem e de animais, que me possa emprestar para uma experiência, digo, demonstração?

Do amigo

F. Fajardo

41, rua Marquês de Abrantes

OBS.: manuscrito feito no verso de um cartão da Associação dos Empregados no Comércio do Rio de Janeiro.

Rua Gonçalves Dias, 40

Amigo dr. Lutz

Escrevi para [?], avisando que lhe mandaria tubos para colher mutucas e mosquitos. $\mathrm{Na}$ noite que fui à sua casa, só pude ir muito tarde, 10 horas, e por isso já estava fechado.

Peço-lhe o obséquio de enviar-me pelo correio o seu retrato, conforme the pedi.

Minha mulher muito se encomenda à sua senhora e eu também.

Seu $\mathrm{am}^{\circ}$ mut $^{\circ} \mathrm{ad}^{\text {or }}$

F. Fajardo

Rio, 14 de março, 06.

41 rua Marquês de Abrantes 
Ilmo. Exmo. sr. dr. Adolpho Lutz

Porque bem sei que trato com um verdadeiro sábio, de grande alma e grande coração, é que me animo a escrever-vos esta carta, não vos conhecendo pessoalmente nem sendo por vós conhecido.

Creio que o dr. Francisco Fajardo já vos avisou por carta do pedido que venho agora fazer-vos e me apresentou; foi isso o que lhe pedi na fé de amigo.

Sendo eu aluno da $6^{\underline{a}}$ série médica da Faculdade daqui e pretendendo escrever a tese sobre as aplicações da bacteriologia ao diagnóstico clínico, tenho procurado obter dos que lidam com o microscópio e com a clínica observações resumidas de casos em que o exame bacteriológico tem decidido o diagnóstico. A tarefa tem sido difícil, pois raros são os que aqui se aplicam às causas da bacteriologia, e como sabeis nem laboratório tem o aluno onde pratique.

E como sei que sois, no Brasil, dos que mais amam e cultivam a microbiologia, ouso pedir o vosso auxílio valioso, que para mim será motivo de gratidão e de ainda maior estima.

Assim, espero da vossa bondade e gentileza ser honrado com a remessa de algumas observações da vossa clínica, em que o diagnóstico tenha sido feito, confirmado ou esclarecido pelo exame bacteriológico.

No caso afirmativo, peço-vos licença para declarar a procedência dos casos clínicos, que nisso, bem certo, estará o maior valor do meu ligeiro trabalho.

Subscrevo-me com consideração

Rio, 13 set. 1895

Vosso admirador e discípulo

Plácido Barbosa*

(Rua Passos Manoel, 20, Laranjeiras, Rio)

*José Plácido Barbosa da Silva destacou-se como tisiólogo, tendo chefiado a Inspetoria de Profilaxia da Tuberculose após a criação do Departamento Nacional de Saúde Pública, em 1920. Já havia publicado Um plano de combate à tuberculose na cidade do Rio de Janeiro (Rio de Janeiro, Typ. Bernard Frères, 1917). É autor também, junto com Cássio Barbosa de Rezende, de uma obra de referência fundamental para os historiadores da saúde: Os serviços de saúde publica no Brasil ... de 1808 a 1907, organizado por do ordem de Oswaldo Gonçalves Cruz (Rio de Janeiro, Imprensa Nacional, 1909). (N. do ed.) 
Ilustrado amigo e sábio mestre sr. dr. Lutz

Ao chegar à nossa casa encontrei pessoa da família doente e por esse motivo vejome impossibilitado de, pessoalmente como era do meu dever, ir despedir-me de V.Sa., agradecer-lhe a honrosa visita com que distinguiu-me e protestar o meu reconhecimento pelos sábios ensinamentos que tão bondosamente ministrou-me. Faço-o por intermédio desta.

Impossibilitado de gozar mais alguns momentos de sua amável e proveitosa companhia, ponho à sua inteira disposição a nossa casa, bem como os meus insignificantes préstimos.

Despedindo-me saudoso, peço vênia para subscrever-me

De V. Sa.

Discípulo e criado $\mathrm{mt}^{\circ}$ admirador

Rio, 11 de março de 95

Gonçalves Cruz*

R. Jardim Botânico, 9

Jardim, 23 de setembro de 1895.

Sábio amigo Ilmo. sr. dr. Lutz

Minhas mais sinceras felicitações pela sua efetiva investidura no cargo de diretor do laboratório que tão brilhantemente dirigis.

Esta tem por fim acompanhar uma preparação de sangue que junto envio e que submeto à sua alta apreciação.

Este sangue foi colhido por picada de dedo num doente que achava-se afetado de uma grande anemia (1.108.000 hemácias por $\mathrm{m}^{3}$ ) e que nunca sofreu de impaludismo, anemia que segundo refere o doente começou após um resfriamento.

A preparação que, seja dito de passagem, não está digna de ser apresentada a um mestre, foi fixada com a solução alcoólica de sublimado a 1:100 e corada com colina. Em alguns pontos (principalmente onde marquei com tinta) observam-se hemácias com o protoplasma repleto de granulações afetando disposições irregulares, fazendo algumas lembrar a forma do hematozoário de impaludismo. Serão simples deformações das hemácias? Será defeito da técnica? Será um hematozoário?

Ansioso espero o seu veredicto.

Brevemente pretendo enviar-lhe uma cultura de um micróbio que estou estudando.

Pedindo desculpas da minha importunação, subscrevo-me

seu discípulo e gde admirador

Gonçalves Cruz

Rua Jardim Botânico, 9

* Oswaldo Gonçalves Cruz (5.8.1872-11.2.1917) doutorou-se na Faculdade de Medicina do Rio de Janeiro em 1892 com tese a respeito Da veiculação microbiana pelas águas. Clinicou no Rio de Janeiro até os primeiros meses de 1896, quando viajou para a França para fazer estudos de aperfeiçoamento. Em Paris, trabalhou no Serviço de Vias Urinárias do professor Félix Guyon, no Laboratório de Toxicologia da municipalidade, e no Instituto Pasteur, então dirigido por Émile Roux. Depois de um estágio na Alemanha, regressou ao Brasil em 1899. Sobre a brilhante carreira de Oswaldo Cruz como clínico, bacteriologista e sanitarista, ver especialmente http://www.prossiga.br/oswaldocruz/ (N. do ed.) 
Rio, 26 de novembro de 1895

Sábio mestre e amigo sr. dr. Lutz

Queira aceitar os meus mais cordiais cumprimentos.

A esta acompanha uma cultura por picada, em ágar, de uma espécie microbiana cromogênea por nós isolada no bulbo das penas de uma galinha afetada de uma espécie de herpes circinado e cuja diagnose não consegui fazer vista não encontrar nos livros de microbiologia que possuo, uma descrição que se adapte a ele.

Eis em resumo os caracteres biológicos que conseguimos verificar:

\begin{tabular}{|c|c|c|c|c|c|c|c|c|}
\hline HÁBITAT & MORFOLOGIA & CALDO & GELATINA & GELOSE & BATATA & PLACAS & $\begin{array}{l}\text { Progr. } \\
\text { biológica }\end{array}$ & $\begin{array}{c}\text { Inocul. } \\
\text { em animais }\end{array}$ \\
\hline $\begin{array}{l}\text { Isolada } \\
\text { do bulbo } \\
\text { das penas } \\
\text { de uma } \\
\text { galinha } \\
\text { afetada } \\
\text { de uma } \\
\text { espécie } \\
\text { de herpes } \\
\text { circinado }\end{array}$ & $\begin{array}{l}\text { Pequenos bacilos } \\
\text { unidos } \\
2 \text { a } 2 \text {, outros } \\
\text { novos } \\
\text { formando } \\
\text { cadeias. } \\
\text { Quase imóveis }\end{array}$ & $\begin{array}{l}\text { Desenvolvem-se } \\
\text { formando no fim de } \\
3 \text { dias, na superfície } \\
\text { do caldo, um véu } \\
\text { branco, } \\
\text { não homogêneo, } \\
\text { semelhante a } \\
\text { gordura, e que } \\
\text { cobre-se no fim de } \\
\text { alguns dias como } \\
\text { que de um pó } \\
\text { amarelado e } \\
\text { avermelhado, } \\
\text { ficando, no fim de } \\
\text { algum tempo, toda } \\
\text { a superfície da } \\
\text { cultura vermelha. }\end{array}$ & $\begin{array}{l}\text { Cresce lentamente } \\
\text { sem liquifaze-la. Ao } \\
\text { longo da picada } \\
\text { forma-se um induto } \\
\text { branco. No ponto } \\
\text { de entrada da } \\
\text { agulha forma-se } \\
\text { uma saliência que } \\
\text { no fim de pouco } \\
\text { tempo toma a cor } \\
\text { rósea que fica mais } \\
\text { tarde vermelha. } \\
\text { Essa saliência } \\
\text { apresenta o aspecto } \\
\text { de uma flor cujas } \\
\text { pétalas semelham } \\
\text { conchas. } \\
\text { A superfície da } \\
\text { gelatina em torno } \\
\text { da cultura torna-se } \\
\text { branca de leite. }\end{array}$ & $\begin{array}{l}\text { Em picada os } \\
\text { mesmos caracteres } \\
\text { da cultura em } \\
\text { gelatina. } \\
\text { Por estria } \\
\text { desenvolve-se } \\
\text { lentamente, } \\
\text { formando pequenas } \\
\text { massas } \\
\text { avermelhadas. }\end{array}$ & $\begin{array}{l}0 \text { desenvolvimento } \\
\text { na temperatura } \\
\text { ambiente é muito } \\
\text { lento. } \\
\text { A cultura é seca e } \\
\text { pulverulenta, não } \\
\text { aderindo a agulha } \\
\text { de platina. Tem a } \\
\text { prinćipio a cor } \\
\text { amarelo de ocre } \\
\text { que passa depois a } \\
\text { vermelho. }\end{array}$ & $\begin{array}{l}\text { Desenvolve-se } \\
\text { com lentidão. No } \\
\text { fim de } 8 \text { dias } \\
\text { apresentam-se } \\
\text { com o volume da } \\
\text { cabeça de um } \\
\text { alfinete, talvez } \\
\text { muito menores, } \\
\text { transparentes, } \\
\text { circulares, } \\
\text { granuladas, } \\
\text { esverdeadas, } \\
\text { apresentando na } \\
\text { parte central } \\
\text { uma saliênnia } \\
\text { que dá à colônia } \\
\text { a forma cônica. } \\
\text { Não liquefaz a } \\
\text { gelatinna. }\end{array}$ & $\begin{array}{l}\text { Aeróbio. } \\
\text { Não produz } \\
\text { pigmento ao } \\
\text { abrigo de ar. } \\
\text { Cora-se bem } \\
\text { pelas cores } \\
\text { básicas de } \\
\text { anilina. } \\
\text { Não se descora } \\
\text { com o processo } \\
\text { de Gram. }\end{array}$ & \begin{tabular}{l} 
Uma partícula \\
da cultura \\
depositada \\
numa bolsa feita \\
na pele do \\
pescoşo de uma \\
galinha nada \\
produziu. \\
\hdashline--- \\
Os ensaios de \\
inoculação estão \\
incompletos
\end{tabular} \\
\hline
\end{tabular}


Dhe, 26 de Townbre de tors $\sigma^{\prime \prime}$

Whie Hoobe e anyo Litaty

Quevir anitar os menos mos eacdeces comprimento

Clata acomparth smen oulturar pro picata en cegar dims a apreie

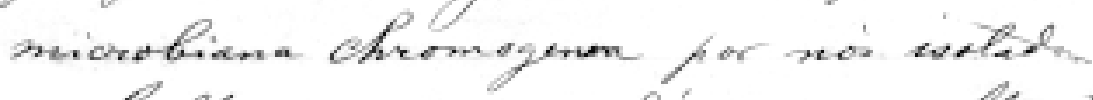
ne bulle da remas 2 'sme gelliniti' affectada d'sm. eapreas de terpeso

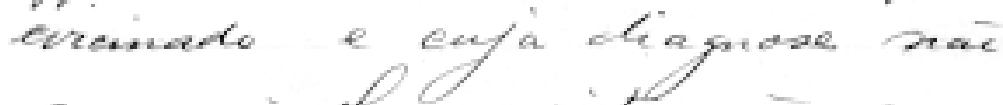
consegm fasior viste naxe crems trat nos tive de microbidegia pue

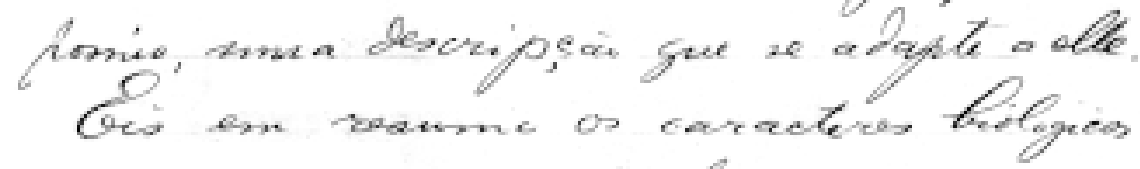
the consegunios nexiflex:

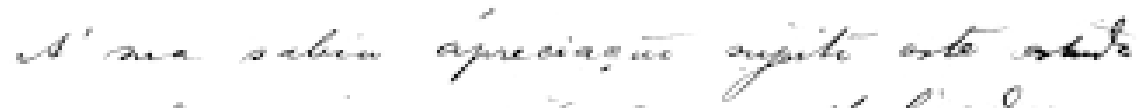

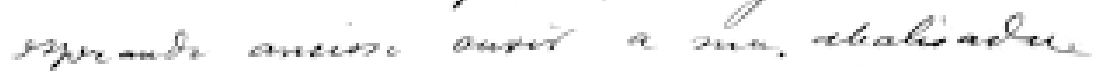
opriniato

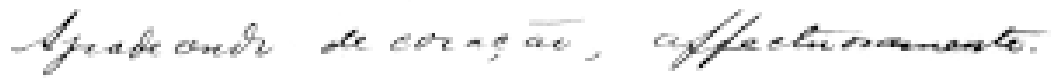
compriments o.

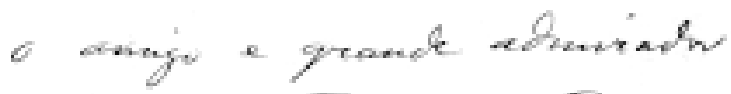

Yonpalow beus

P. \%ordin Batance 9-

330

História, Ciências, Saúde — Manguinhos, Rio de Janeiro 


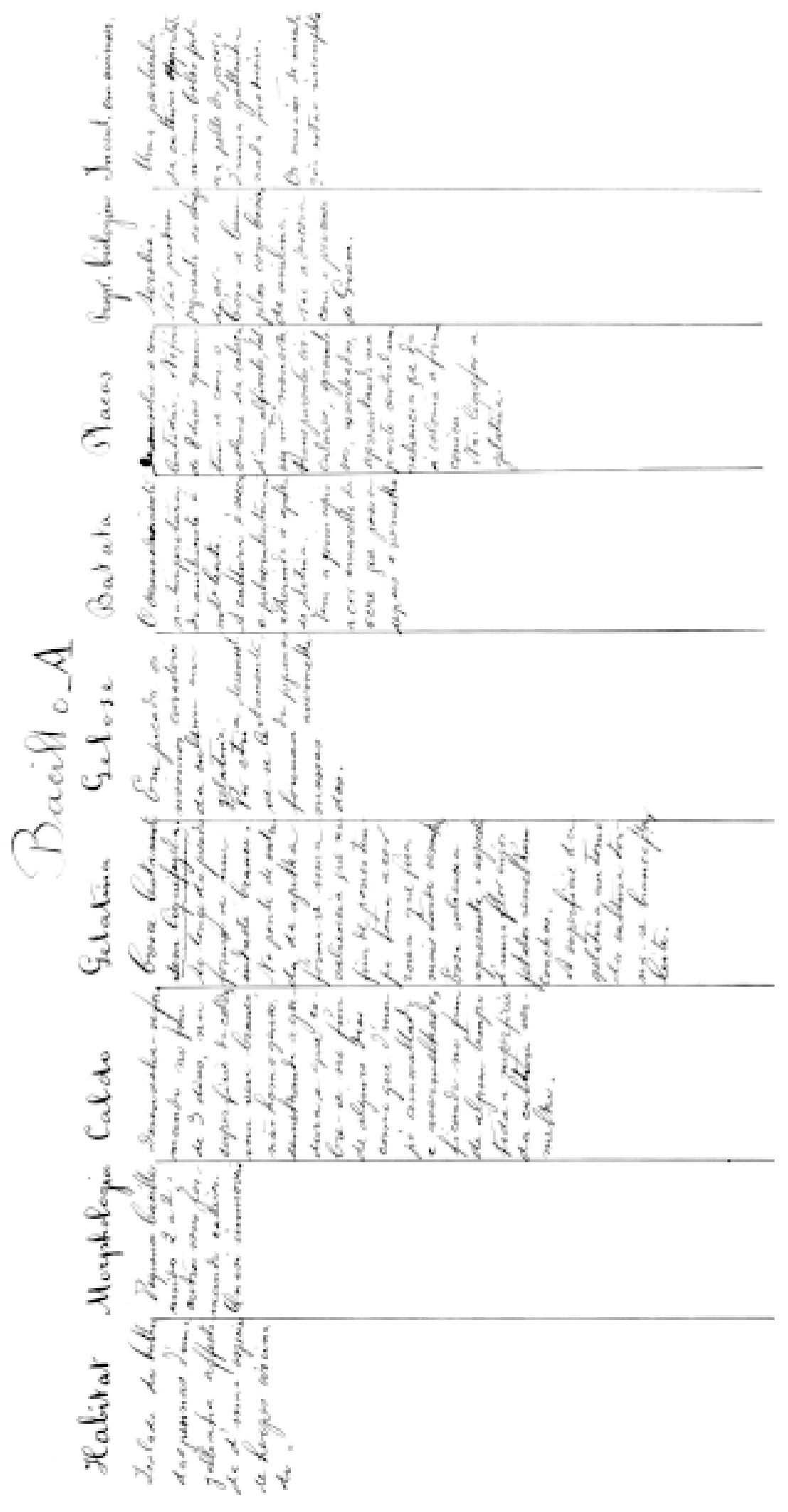

vol. 10(1):287-409, jan.-abr. 2003 
Jardim, 27 de maio de 1895.

Sábio mestre e prezado amigo dr. Lutz

Muita saúde é o que mais lhe desejo.

Tenho feito alguns estudos sobre sangue de pássaros, porém sem resultado no que se refere aos hematozoários; continuarei as pesquisas e qualquer resultado positivo ser-lhe-á imediatamente comunicado.

Verifiquei a presença da Amoeba coli de Laesch, num caso de disenteria e consegui acompanhar e desenhar os movimentos de uma delas. Junto envio-lhe o desenho obtido. Num outro caso da mesma moléstia não logrei ver o referido protozoário.

Acabo de receber o trabalho de Davidson e vou imediatamente dar começo à parte que me coube, isto é: a febre de Malta e a dengue. Se fosse possível teria muito desejo de encarregar-me de estudo sobre a framboésia (p. 511) e para isso peço a sua autorização, caso o colega dela encarregado queira ceder-me.

Esperando sua resposta, tenho a honra de subscrever-me

Seu discípulo, amigo e $g^{\text {de }}$ admirador

Gonçalves Cruz

Rua Jardim Botânico, 9 
Hamburgo, dia 24 de maio de 1895.

Mui estimado senhor doutor!

A resposta às suas amigáveis linhas delongou-se indevidamente porque eu mesmo me vi recentemente muito sobrecarregado de trabalhos, e por ter o assistente incumbido de testar suas culturas adoecido entrementes.

A seguir apresento-lhe uma breve sinopse dos resultados das investigações comparativas que empreendemos com seus vibriões.

Com relação à cultura no 1 só posso concordar com a sua opinião de tratar-se de genuínos vibriões de cólera. As colônias são bem típicas, apenas a liquefação surge muito lentamente tanto nelas, como nas culturas semeadas em gelatina.

Pela reação específica ao cólera de Pfeiffer, estes vibriões comportam-se de maneira inteiramente positiva. A cultura 2, isolada das fezes, comportou-se de maneira idêntica.

A cultura 3, Vibrio-morrhuae, estava morta quando a recebemos. Koch.

Cultura 4: achamo-la também, na maioria dos pontos, diferente dos vibriões de

V. S. se interessará em saber que esta cultura se comporta de modo inteiramente negativo no teste sorológico de Pfeiffer.

As culturas solicitadas por V. S. serão enviadas amanhã pelo sr. dr. Neumann a seu endereço. Infelizmente não há mais separatas disponíveis de meu trabalho sobre vibriões publicado pela Imperial Repartição de Saúde (Kaiserlichen Gesundheitsamte).

Com o pedido de que perdoe o grande atraso em responder-lhe, saúda-o cordialmente.

Com a maior consideração,

Seu devotado,

Dr. Dunbar*

* William Philipps Dunbar teve atuação marcante na epidemia de cólera que irrompeu na Europa Central em agosto de 1892, atingindo semanas depois a cidade de Hamburgo, onde foram contabilizados 17 mil pessoas doentes e quase nove mil mortos. Robert Koch supervisionou as medidas profiláticas postas em prática naquela próspera cidade portuária, e depois de debelada a epidemia, seu colaborador Georg Theodor Gaffky assumiu o cargo de conselheiro de questões higiênicas e diretor de pesquisas bacteriológicas. Em fevereiro de 1893, Dunbar, que era assistente de Gaffky, foi nomeado diretor do Instituto Higiênico criado em 28.12.1892. (N. do ed.) 
Hamburg, den 24 Mai 1895

Sehr geehrte Herr Doctor!

Die Beantwortung Ihrer frdl.[ichen] Zerlen hat sich ungebührlich lang hingezogen, weil ich selbst kürzlich sehr mit Arbeiten überhäuft und der mit der Prüfung Ihrer Culturen beauftragte Assistent inzwischen erkrankt war.

Nachstehend gebe ich Ihnen eine kurze Übersicht über die Ergebnisser verg leichender untersuchungen, die wir mit Ihren Vibrionen angestellt haben.

Betreffend Cutur $\mathrm{n}^{\circ} 1$ kann ich Ihner Ansicht, daß es sich um echte choleravibrionen handelt, nur beistimmen.

Die Colonien sind annährend typisch, mur tritt die Verflüssigung hier wie in den gelatinstichen sehr langsam auf.

Nach der Pfeiffer schen specifischen Galinareaction geprüft verhalten sich diese Vibrionen sich durchaus positiv. Cultur 2, aus Ihrem Stuhl isoliert, verhielt sich ebenso.

Cultur 3 Vibrio morrhuar war bei Empfang abgestorben.

Cultur 4 fanden auch wir in den meisten Punkten verschieden von den Koch'schen Vibrionen.

Es wird Sie interessieren zu hören, daß diese Cultur auf die Pfeiffer's. che Serumsprüfung sich durchaus negativ verhält.

Die von Ihnen gewünschte Culturen werden morgen durch Herrn Dr. Neumann na Ihre Adresse abgesandt (werden) heides stehen Separatabdrücke von meines in den Arbeiten aus dem Kaisereichen Gesund heitsamte veröffenteichen Vibrionenarbeit nicht mehr zu Verfügung.

Mit du Bitte, du lange Verzögerung entschuldigen zu wollen, bin ich mit herzlicher Enopfehlung

hochachtungsvoll

Ihr ergebener 
Hotugienisthes forstitut.

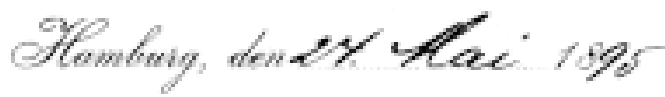

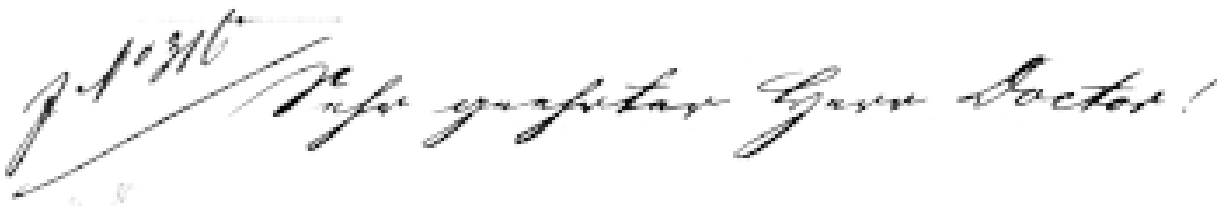

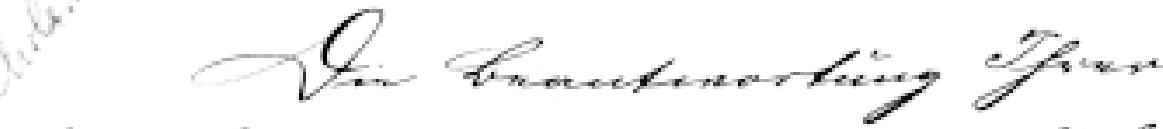

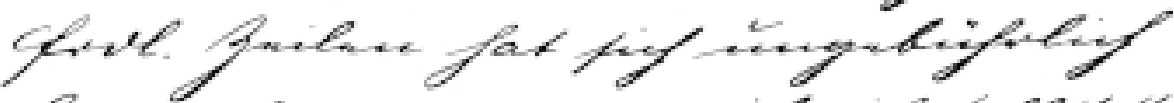

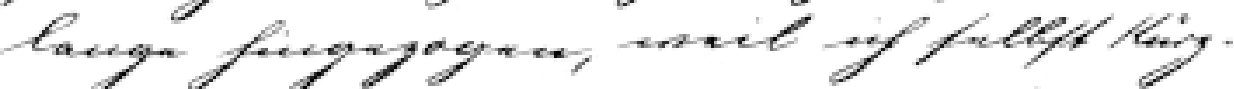

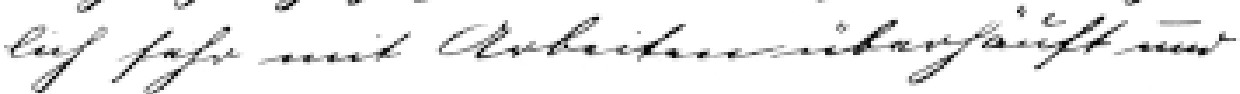

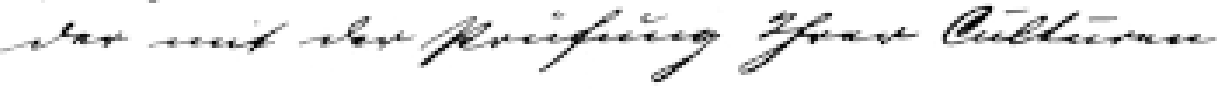

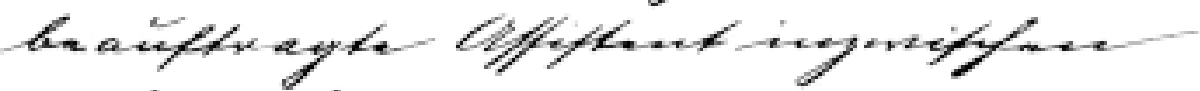
whrowht eniar

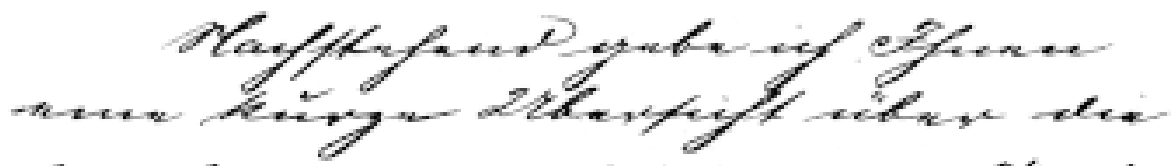

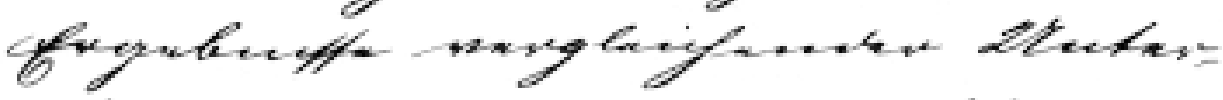

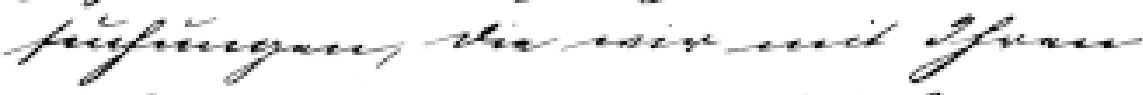

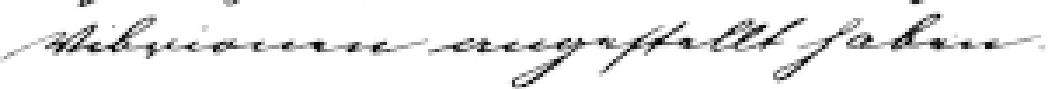

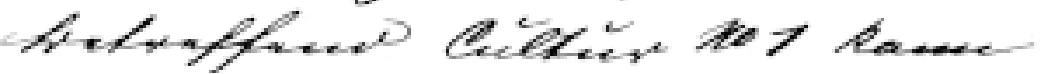

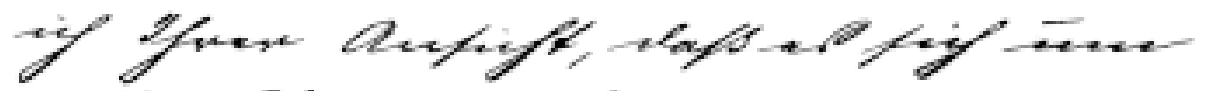
nyll ehoheravituenuen fautelt netre krifticuncene.

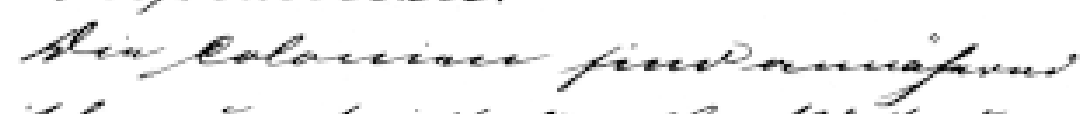

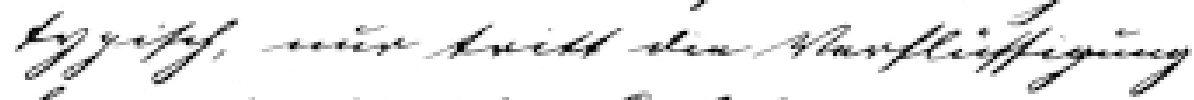

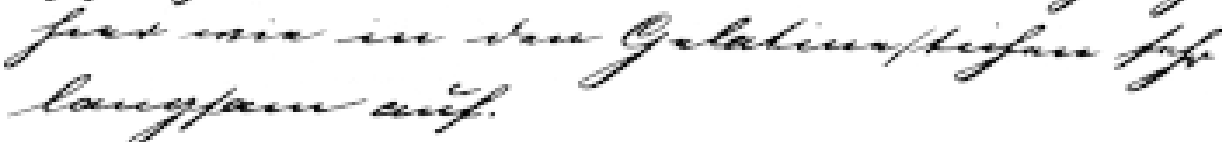

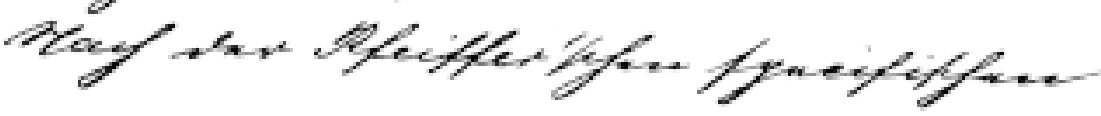




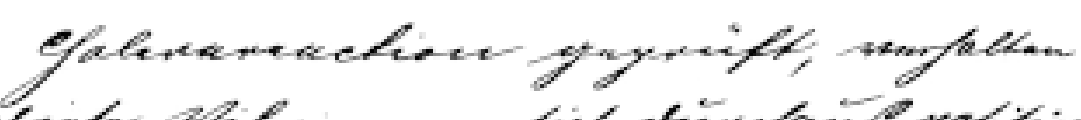

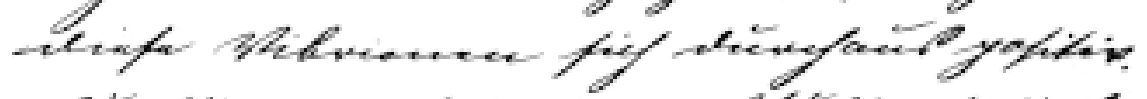

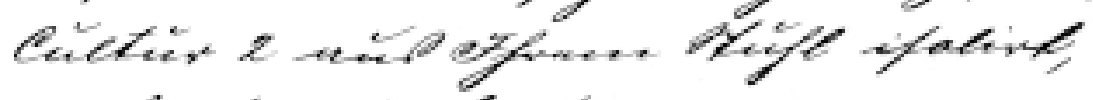
mayfialt fig whents.

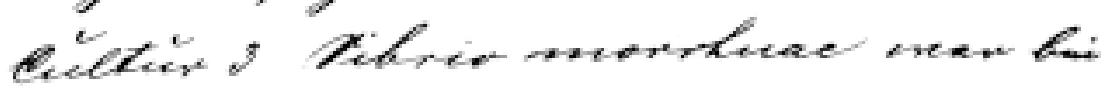
fougfary orlyoftarkw

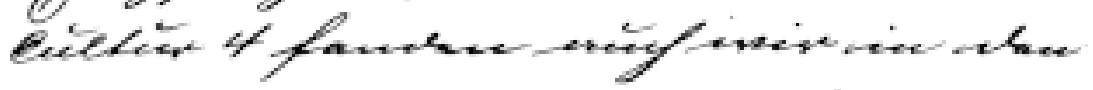

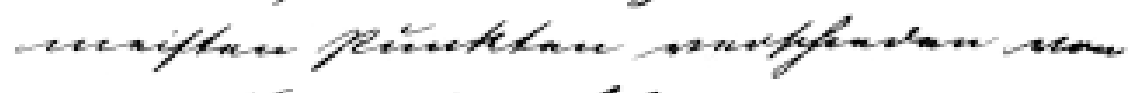

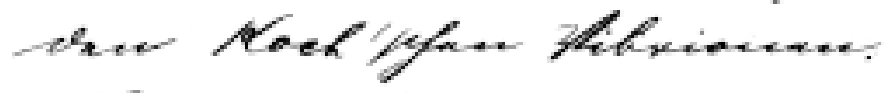

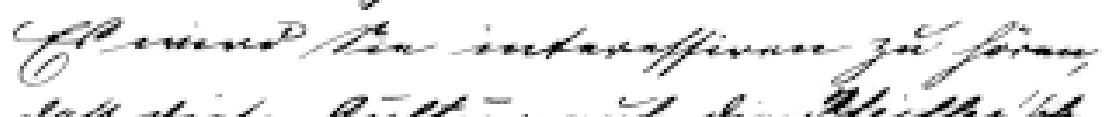

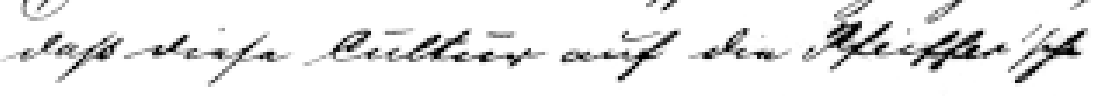

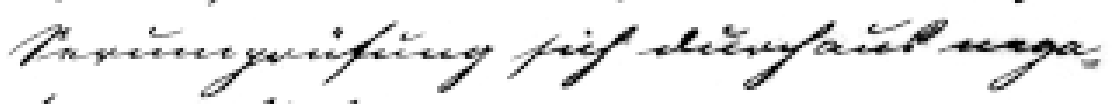
him manfict

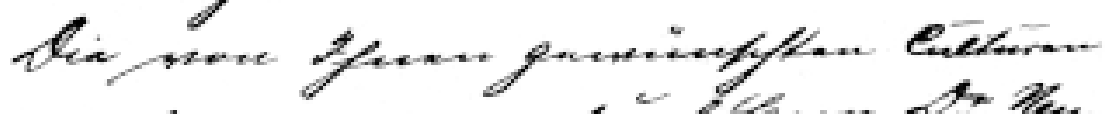

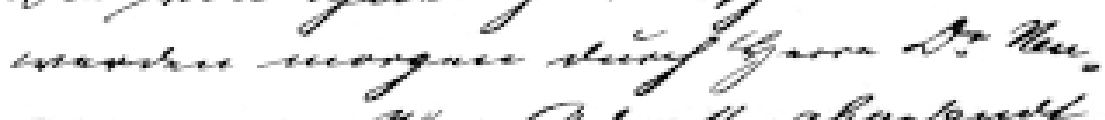

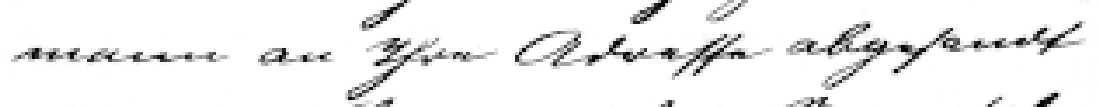

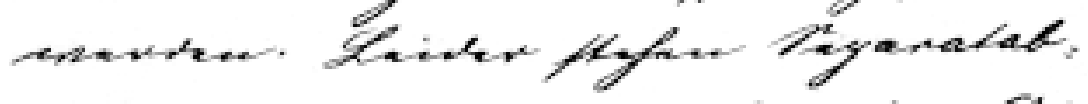

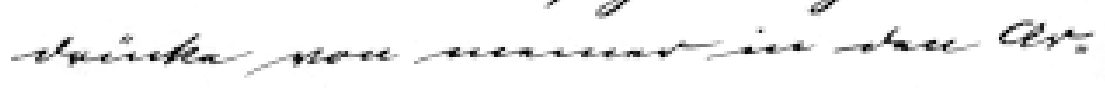
bukn wite de... Maif weif...

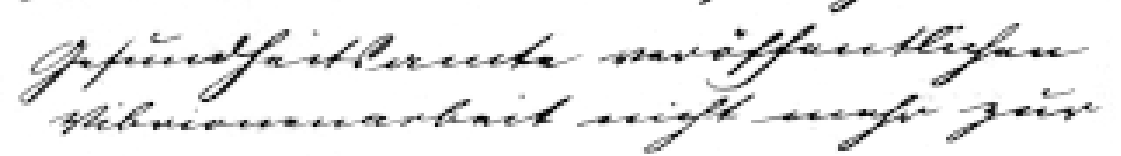
Haxfingrang

bit ster hith, dei langer

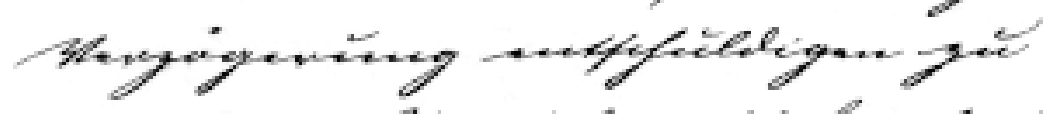
uncher, bive of mit faryhigh tongtafleing

joyfarficenghede

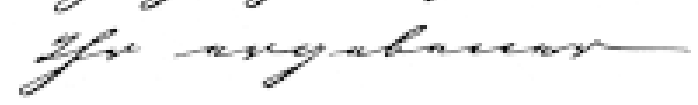

336

Mituatar. 
Mui estimado senhor doutor!

Foram-me entregues (em mãos) pelo sr. dr. Echeverria, nos primeiros dias de agosto, duas culturas do sr. Lutz, de São Paulo, das quais uma deveria conter bacilos de tifo, a outra, vibriões coléricos de Koch.

Já que ambas as culturas, apesar da selagem com parafina, pareciam muito danificadas, fato para o qual chamei a atenção do sr. dr. Echeverria, na ocasião, decidi providenciar sem demora a colocação dos microorganismos em boas condições de desenvolvimento.

Infelizmente isso não foi possível, apesar de todos os procedimentos adotados com tal finalidade. As culturas morreram na longa viagem.

Pelo mesmo motivo, a preparação com corantes feita diretamente a partir das culturas não ofereceu nenhum (ilegível) quadro característico, apenas (ilegível), de maneira que neste caso, também, não se conseguiu chegar a algum parecer, e sim ao lixo.

Talvez o sr. dr. Lutz queira fazer nova remessa, especialmente dos vibriões. Neste caso, aconselharia não utilizar a selagem dos tubos de ensaio com parafina, mas tubinhos que possam ser selados com facilidade, fundindo-se a abertura na chama de um bico de gás. Dessa maneira as culturas se conservam por muito tempo.

Com distinta consideração,

Seu dedicado

Dr. Oergel

\section{$26 / 1894$}

Estimado dr.

Estive algumas semanas afastado por causa do Congresso da Associação Médica Britânica, em Bristol. Na minha ausência, o sr. dr. Echeverria (futuro diretor do Instituto de Higiene em Costa Rica, que trabalhava comigo), a meu pedido levou imediatamente parte das culturas que chegaram para o Instituto de Higiene de Hamburgo, e enviou outra parte para Halle. De Eberth, ainda não tive resposta, embora tenha também solicitado sua opinião. Julguei mais salutar o Instituto de Higiene daqui do que o de Berlim, já em nenhum lugar se trabalha mais com cólera do que aqui, e entre o pessoal (dr. Dunbar) há conhecidos meus, mais amáveis, portanto, do que Koch e os kochianos. Pareceu-me que seria mais vantajoso para o senhor enviar-lhe logo a carta do assistente de Dunbar, sem esperar pela resposta de Eberth, para que possa remeter imediatamente novas culturas, com os vidros hermeticamente fechados. Minha histopatologia provocou algum furor na Inglaterra, e provavelmente será traduzida para o inglês.

Seu Unna*

"Sobre o dermatologista Paul Gerson Unna (1850 -1929), ver nota 14 de 'Adolpho Lutz: um esboço biográfico' neste número da revista. (N. do ed.) 
Hamburg, den 25 August 1894

Sehr geehrter Herr Doctor!

Von Herrn Dr. Echeverria wurde mir in den ersten Tagen des August 2 Culteren von Herrn Dr. Lutz aus St. Paulo flammend übergeben, von denen eine Typhusbacillen, die andere Koch'sche Choleravibrionen enthalten jollten.

Da beide Culturen troty des Parafinverschlusses sehr [...] aussahen, vorauf ich Herrn Dr. Echeverria damals aufmerksam machte, so waren meine Maßnahmen sofort darauf gerichtet die Mikro organismen wuds in ein gut entwicklungfähigen Zustand zu setzen.

Leider ist dieses bei allen darauf abzrelenden Verfahren nicht mehr möglich gewesen - die Culturen waren auf der langen Reise abgestorben.

Demgemäß gab auch das gefärbte Präperat direckt aus den Culturen kein [...]

Charakteristisches Bild, sondern nur [...] ten losen [...], so daß auch hiernach kein Urteil über die [...] formen gewonnen soudern unrat.

Viellericht wird Herr Dr. Lutz seih zu einer neuen Sendung speciell der Vibrionen entschließen können. Ich würde in deisen Fall empfehlen micht Parafin abschluß der Reagenzgläschen anzuwenden soudern [...] Röhrchen, wie es mit einem Gebläse sehr leicht gelingt direckt zuzuschmelzen. Auf diese Weise halten seih Culturen sehr lange.

\author{
Mit vozügliche Hochachtung \\ Ihr \\ ergebenster \\ Dr. Oergel
}

$26 / 894$

Lieber Dr.,

In meiner Abwesenheit - ich war einige Wochen fort wegen des Congr. Der Brit. Med. Ass. In Bristol, hat Herr Dr. Eccheverrria (zukunft Direktor d. hygien. Inst. Zu Costa Rica), der bei mir arbeitet, wie ich ihnr aufgetragen, die Culturen, die inzuwischen angekommen, sofort theils in das hiesige Hyg. Institut, theils nach Halle geschickt. Von Eberth habe ich, obwohl ich sofort auch um Rückkunft anfragte, was seine Ansicht wäre, noch keine Antwort. Das hiesige hygien. Institut fand ich gesunder als Berlin, da niergends mehr cholera jetzt gearbeitet wird als hier $u$. die heute (Prof. Dunbar) mir persönlich bekannt und liebens würdiger sind als Koch und die Kochianer. Jetzt ist's mir in Ihrem Sinne auch lieber so u. ich sende Ihnen den Brief von Dunbar's Assistenten gleich, ohne auf Eberths Antwort zu warten, damit Sie sofort neue Culturen in hermetischen glasabschluß absenden können. Meine Histopathologie hat in England einiges Furor gemacht; wahrsechein lich wird sie ins Engl. übersetzt.

Ihr. Unna 


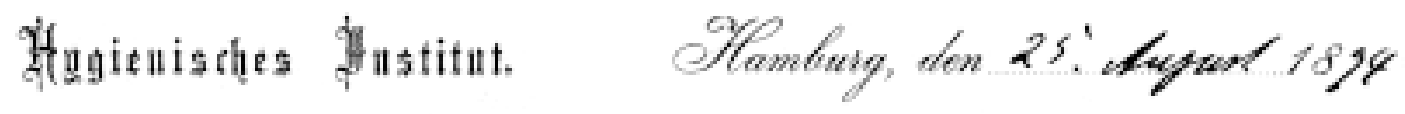

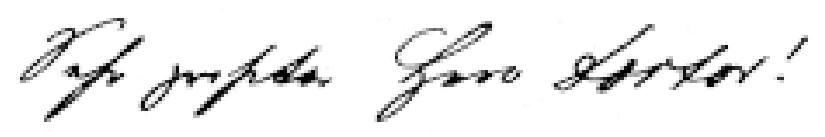

Llen Som or Levernia nuins.

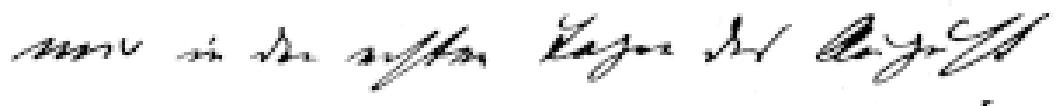

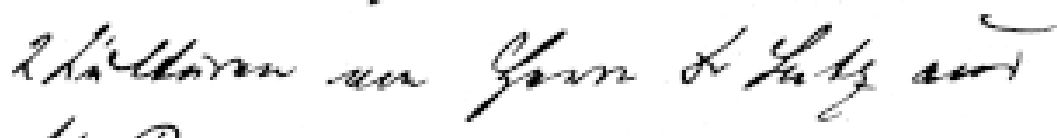

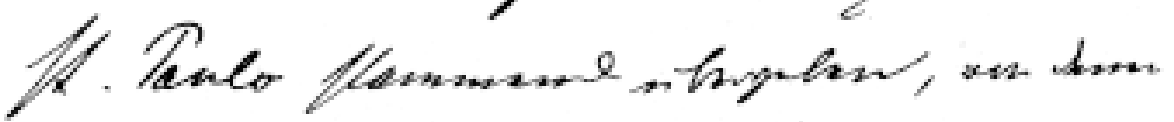

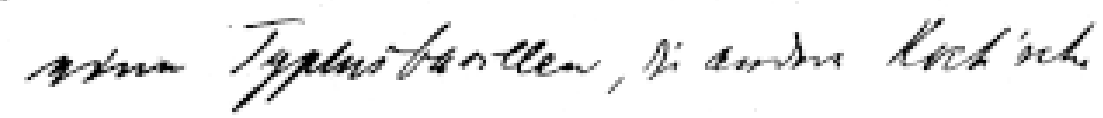
Cholesuntriatew antelton freltean.

of hir fallow tory os

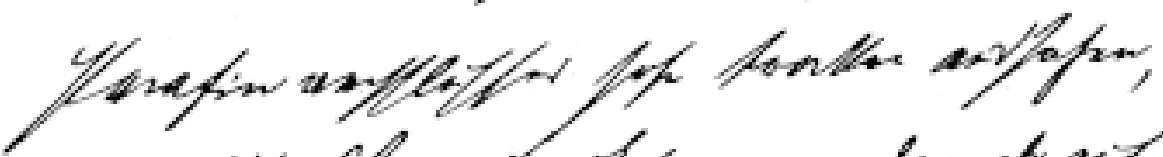
noraty Gem of ticeverre semet axf

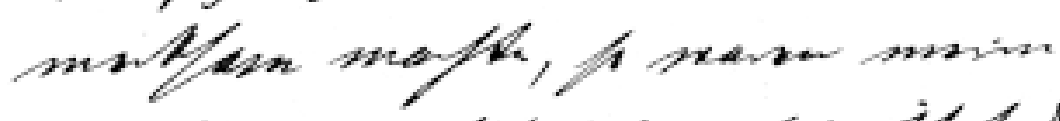

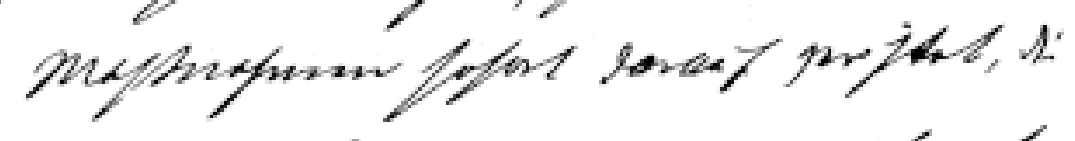

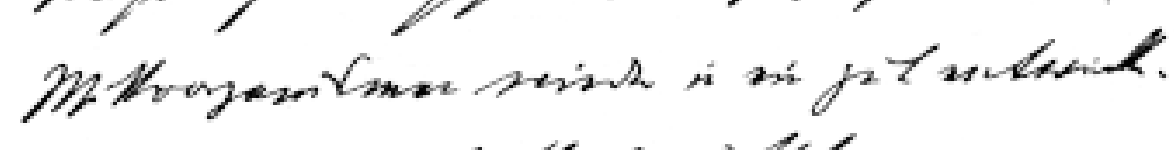

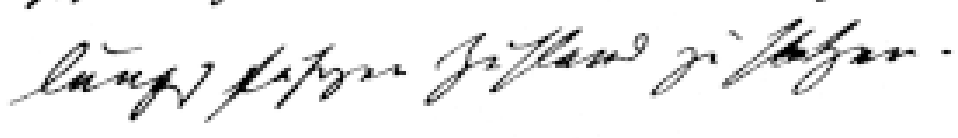

vol. 10(1):287-409, jan.-abr. 2003

339 


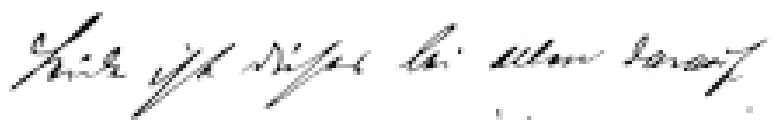

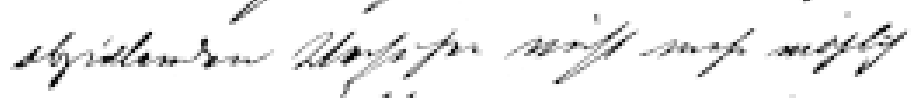

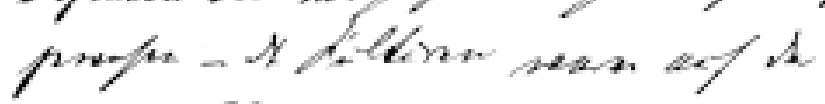
lexper. Res etfrlentax.

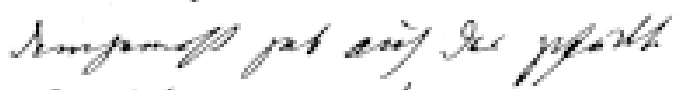

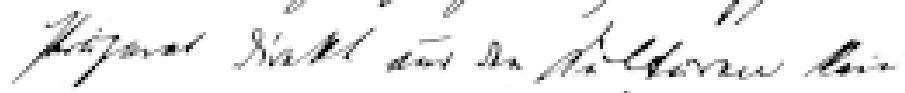

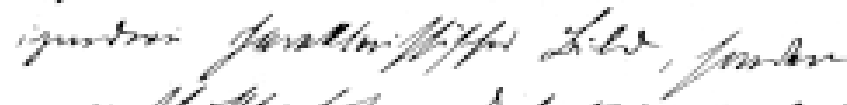

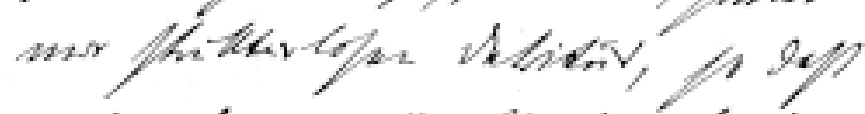

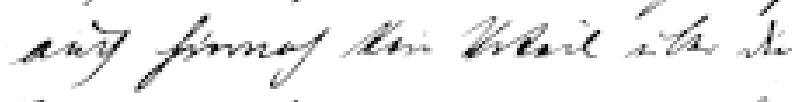

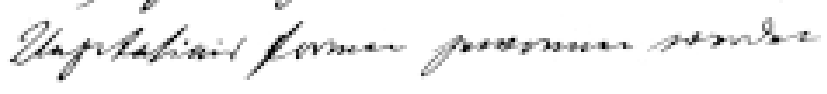
Lims.

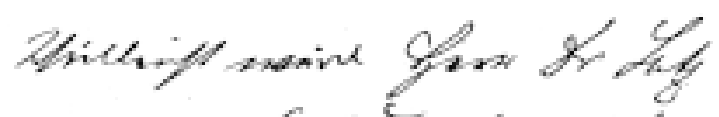

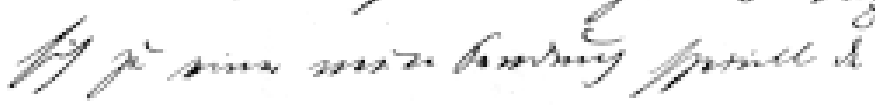

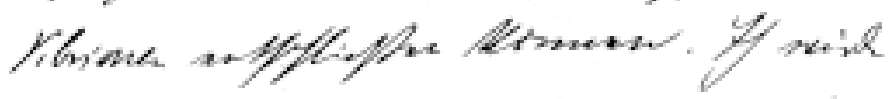

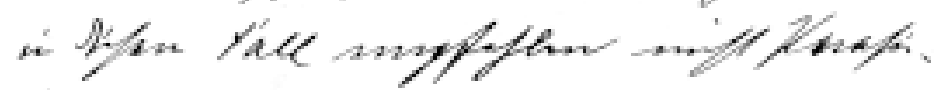

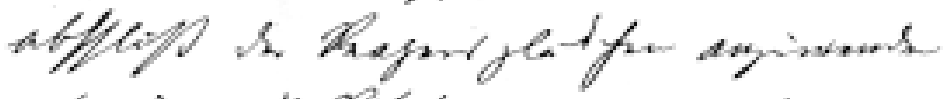

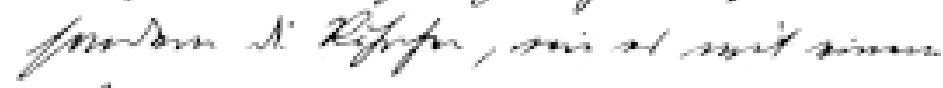

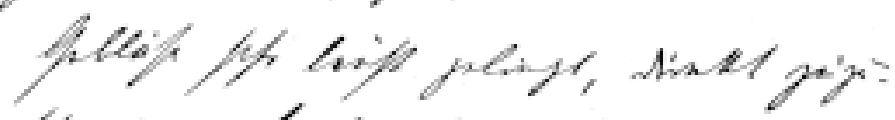

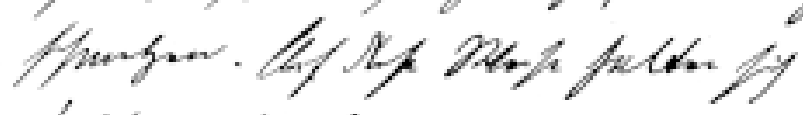
dienom lip ling.

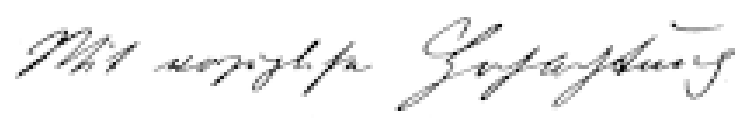

mplath

froent.

340 
São Joaquim da Costa da Serra

29.4.1917

Est. de S. Catharina

Ao sábio colega senhor dr. Adolfo Lutz

\section{Afetuosos cumprimentos!}

Envio um pequeno tubo com algumas espécies de muscídeos e tabanídeos que colecionei no mês de março a. c., no planalto de São Joaquim da Costa da Serra (Santa Catarina) e de Vacaria (Rio Grande do Sul) que se eleva nesta região até $1.750 \mathrm{~m}$ sobre o nível do mar.

Peço recomendar-me ao nosso ilustrado colega senhor dr. Arthur Neiva.

O grato amigo e sincero admirador Jorge Bleyer*

*Sobre Georg Carl Adolf Bleyer (21.1.1867-1955), ver nota de pesquisa intitulada 'Caminhos percorridos pelo dr. Jorge Clarke Bleyer nos campos da medicina tropical e da pré-história brasileira', neste número da revista. (N. do ed.) 
Mui estimado senhor doutor,

Permito-me enviar-lhe meus melhores votos para um abençoado ano-novo.

Valho-me da ocasião para remeter-lhe uma caixinha contendo três vidros com algumas coletas:

O vidrinho $\mathrm{n}^{\mathrm{o}} 1$ mostra um exemplar fêmea de escorpião com jovens os quais a mãe carrega de maneira a protegê-los na parte anterior do tórax.

O vidrinho no 2 contém dois assim chamados piolhos plunícolas do corpo de uma garça "colhereiro" (Ajaja).

O vidro no 3 contém, entre outras coisas, tabanídeos de espécies conhecidas; talvez só sejam bem-vindas para conhecer o âmbito de sua distribuição geográfica.

Ser-lhe-ei muito grato pelo envio de um exemplar das Memórias do Instituto Oswaldo Cruz que ostenta a belamente sucedida ilustração de Triatoma megista de Carlos Silva (do ano 1911).

Em anexo, enviei separatas de duas modestas memórias de meu âmbito de observação.

Com cordiais saudações

Geo. Clarke Bleyer

Endereço

Atualmente:

Campos Novos

via Estação Herval

11.1.1926 Estado de Santa Catarina

\section{Hochverehrter Herr Doctor!}

Erlaube mir Ihnen meine besten Wünsche für ein gesegnetes Neujahr zu übersenden. Ich nehme die Gelegenheit wahr Ihnen ein Kästchen zu schicken, welches drei Gläser enthält mit einigen Fundstücken:

Das Gläschen $n^{\circ} 1$ zeigt einen Scorpion, weibliches Exemplar, mit den jungen Tieren, welche die Mutter an der Vorderbrust schützend trägt.

Das Gläschen no 2 enthält zwei sog(enannte) Federlinge vom Körper eines Reihers "colhereiro" (Ajaja)

Das Gläschen no 3 enthält u(nter) a(nderem) Tabaniden bekannter Species; vielleicht würde nur ihr geogr(aphischer) Verbreitungskreis zu ersehen willkommen sein.

Ich würde sehr dankbar [sein] für die Übersendung eines Exemplares der Memórias do Instituto Oswaldo Cruz, welches die schön gelungene Abbildung der Triatoma megista von Castro Silva zeigt (aus dem Jahre 1911)

Anliegend sende ich zwei Separatabdrücke besecheidener Abhandlungen meines Beobachtungskreises.

Mit herzlichen Grüßen

Adresse

Zur Zeit:

Campos Novos

Via Estação Herval

11.1.1926 Estado de Santa Catarina 
Mui estimado senhor doutor,

Recebi suas bondosas linhas de 22 de junho deste ano, bem como três Memórias do Instituto Oswaldo Cruz; meu penhorado agradecimento.

Regozijei-me de coração com o artigo que lhe foi dedicado pessoalmente pelo dr. Carlos Chagas, "como homenagem da mais alta admiração".

Espero corresponder a seu pedido de enviar material para seus estudos nos meses de novembro e dezembro.

Meu filho, Hilário Neves Bleyer encontra-se no Rio de Janeiro para fazer compras para sua pequena farmácia na cidade de São Joaquim, e para submeter-lhe um manuscrito que redigi sob o título 'Um caso de deformação congênita de ambas as extremidades inferiores e superiores acompanhada de tireoidite e outros sintomas mórbidos que revelam a moléstia de Chagas (Careotrypanosis chagasi Lutz)... O talento artístico da moça sertaneja', com fotografias originais e trabalhos originais de doentes que os podem executar e um atestado natural da habilidade artística das mesmas.

Além disso, tenho quase acabado o seguinte trabalho:

'Para o conhecimento da aplicação de terapia com ídolos da medicina mística no tratamento de mordidas de serpentes peçonhentas (ofidismo) por parte dos médicossacerdotes Waikelong Pahý, pajés dos botocudos xocleng, em vias de extinção, pela administração do coração, do fígado e da bile das serpentes peçonhentas', com cerca de dez fotografias originais.

Minha coleção de ídolos contém cerca de 120 objetos desta curiosa terapia que permitem analogias com as práticas de sacrifícios da antiga cultura tucano e dos mexicanos. Estou disposto a oferecer alguns destes preciosos achados a instituições do país.

Talvez V. S. encontre na biblioteca do Instituto Oswaldo Cruz o 2 ㅇ volume do XX Congresso Internacional de Americanistas, Imprensa Nacional, 1924, que deverá conter um trabalho meu. Até agora não recebi o referido volume; veja, por favor, e comuniqueme quais ilustrações se encontram nele. Após boa informação, vou tentar conseguir o volume na Imprensa Nacional.

Talvez me seja possível fazer no mês vindouro uma pequena viagem ao Rio.

Permita-me remeter algumas fotografias de minha coleção de ídolos.

Com cordiais saudações e alta estima colegial,

seu mui devoto,

Presentemente:

Campos Novos

via estação Herval

Estrada de Santa Catarina 


\section{Hochverehrter Herr Doctor!}

Ihre gütigen Zeilen vom 22. Juni d[ieses] J[ahres] habe ich empfangen, ebenfalls drei Memórias do Instituto Oswaldo Cruz; meinen verbindlichsten Dank.

Ich habe mich herzlich gefreut über den Ihnen persönlich gewidmeten Aufsatz von Dr. Carlos Chagas "como homenagem da mais alta admiração".

Ihrer Bitte wegen Übersendung von Material für Ihre Studien hoffe ich in den Monaten November und Dezember entsprechen zu können.

Mein Sohn Hilario Neves Bleyer befand sich in Rio de Janeiro um Einkäufe für seine kleine Apotheke in Cidade de São Joaquim zu machen und um Ihnen bei dieser Gelegenheit ein Manuscript vor zu legen, welches ich unter den Titel vefasst habe: 'Um caso de deformação congênita de ambas as extremidades inferiores e superiores acompanhada de tireoidite e outros sintomas mórbidos que revelam a moléstia de Chagas (Careotrypanosis chagasi, Lutz)... O talento artístico da moça sertaneja'; mit Original-Photographien und Original-Arbeiten der Kranken, welche dieselben ausführen kann und dem von Natur beglaubigten Attesten[?] über die Kunstfertigkeit derselben.

Ferner habe ich folgende Arbeit fast vollendet: 'Zur Kenntnis der Anwendung der Idoltherapie oder Medicina Mistica bei der Behandlung des Giftschlangenbisses (Ophidismus) von Seiten der Priesterärzte Waikelong Pahý Pajés der aussterbenden Schockleng Botocuden unter Darreichung des Herzens, der Leber und der Galle der Giftschlangen' mit etwa 10 Original Lichtbildern.

Meine Idolsammlung enthält etwa 120 Objecte dieser merkwürdigen Therapie, welche Analogien zuläßt mit den Opferhandlungen der alten Tucunacultur und der Mexicaner. Ich bin gern bereit einige dieser wertvollen Fundstücke hiesigen Institutes zu überreichen.

Vielleicht finden Sie in der Bibliothek des Instituto Oswaldo Cruz den II. Band (vol. II) des XX Congresso Internacional de Americanistas, Imprensa Nacional, 1924, welcher eine Abeit von mir enthalten dürfte. Ich habe den betreffenden Band bisher nicht empfangen; sehen Sie, so bitte ich, nach und teilen Sie mir mit welche Illustrationen vorhanden sind. Ich werde auch gütiger Kenntnisgabe vol. II von der Imprensa Nacional zu beziehen suchen. Vielleicht wird es mir möglich sein in kommenden Monaten eine kleine Reise nach Rio unternehmen zu können.

Ich erlaube mir einige Lichtbilder meiner Idolsammlung zu übersenden.

Mit herzlichen Grüßen und kollegialer Hochachtung

Geo. Clarke Bleyer Ihr sehr ergebener

Gegenwärtig: Campos Novos via Estação Herval Estado de Santa catarina 28.III.1927 
Cidade de Lajes, Santa Catarina

14.V.1929

Mui estimado senhor doutor,

Pela amável atenção em remeter dois exemplares $\mathbf{O} / \mathbf{Q}$ de Aedes fasciatus ficar-lheia agradecido. Exemplares a seco.

Enviei-lhe um vidrinho com espécies de tabanídeos e uma rã viva que me chamara a atenção em março deste ano, em São Joaquim.

Como sempre com sincera e elevada estima e saudações colegiais

Seu mui devoto

Geo. Clarke Bleyer

Cidade de Lajes, Santa Catarina

14.V.1929

Hochverehrter Herr Doctor!

Für die liebenswürdige Aufmerksamkeit einer Übersendung von 2 Exemplaren $\boldsymbol{O} / \boldsymbol{Q}$ von Aedes fasciatus würde ich dankbar sein. - Trockenexemplare. -

Ich sendete Ihnen ein Gläschen von Tabanidenspecies und einen lebenden Frosch, welcher mir auffiel im März d.J. von São Joaquim.

Wie immer mit aufrichtiger

Hochachtung und collegialer

Grüßen

Ihr sehr ergebener 
Cidade de Lajes, 1ำ de janeiro de 1932

Santa Catarina

Mui estimado senhor doutor,

Permito-me enviar a V. S. pelo ano-novo meus cordiais votos de felicidade e bênção na esperança de querer Deus permitir que viva ainda muitos anos no seio de sua prezada família, rodeado por um nobre círculo de amigos, podendo contemplar em retrospecto uma atividade abençoada quase toda dedicada à ciência.

Talvez me será possível viajar ao Rio nos meses mais frescos deste ano para mostrarlhe, em parte, o singular material concernente a meus estudos paleoentomológicos.

Com os melhores votos para o seu bem-estar pessoal,

Inteiramente devotado,

Georg C. Bleyer

Cidade de Lajes, 1. Januar 1932

Santa Catarina

\section{Hochverehrter Herr Doctor!}

Erlaube mir lhnen zum neuen Jahre meinen herzlichen Glück - und Segenswunsch zu übersenden, in der Hoffnung, daß es Gott zulassen möge, inmitten lhrer geschätzten Familie noch viele Jahre zu verleben, umgeben von einem edlen Freundschaftskreise und zurückblickend auf eine segensreiche Tätigkeit, welche fast ganz der Wisseschaft gewidmet wurde.

Vielleicht wird es mir möglich sein, in den kühleren Monaten d[ieses] J[ahres] nach Rio de Janeiro zu reisen, um lhnen das so merkwürdige Material zum Teile vorlegen zu können, welches meine paläo-entomologische Studien betrifft.

Mit den besten Wünschen für $\mathrm{lhr}$ persönliches Wohlergehen

Ganz ergebenst

Georg C. Bleyer 
Cidade de Lajes, Santa Catarina

\section{1 .1934}

Mui estimado senhor doutor,

Permito-me enviar-lhe pelo ano-novo meus mais cordiais votos de felicidade e bênção, queira Deus, no interesse de sua prezada família e da ciência, conceder-lhe ainda muitos anos de profícua atividade.

V. S. escreve estar se sentindo algo debilitado, talvez lhe faria bem abster-se algum tempo de todo trabalho intelectual.

Uma estada em uma calma moradia de Teresópolis ou Petrópolis durante os meses mais quentes num ar fresco, rico em oxigênio, deleitando-se com uma dieta de frutas e exercícios físicos opera amiúde milagres. Suco de uvas, [ilegível] grape juice (ilegível) é freqüentemente tomado com prazer por pessoas muito ativas debilitadas intelectualmente, mesmo sem diluição. Reforçado ainda com fósforo sob forma do preparado de fósforo em forma solúvel da Park Davis etc.

Na expectativa que V. S. possa interessar-se por minhas modestas pesquisas arqueológico-médicas permito-me comunicar o que segue:

Nas grutas e cavernas de São Joaquim com elevações até $2.100 \mathrm{~m}$ sobre o nível do mar encontrei, entre outras coisas, os ídolos* de dípteros** hematófagos e hemípteros como também achei modelos líticos de [ilegível] aves, além de numerosos instrumentos líticos de sacrifício e objetos (facas de várias formas, almofarizes, raladores etc.) usados para fins médicos e farmacêuticos que eram usados apenas pelos médicos-sacerdotes de tribos extintas em medicina mística ou medicina idólatra. Nenhum museu europeu ou americano possui tais achados que são de extraordinário valor para a história da medicina. Alguns modelos de moscas (espécies hematófagas mostrando o rastro vulnerante) são muito grandes.

Acalento o anelar desejo de fazer na primavera uma viagem à Europa.

Talvez me seja possível fazer no próximo mês uma excursão ao Rio de Janeiro, ocasião em que me permitirei fazer-lhe uma visita.

Com os melhores votos para o seu bem-estar pessoal,

Seu mui devoto

J. C. Bleyer

Notas do autor:

*Minha coleção contém mais de 250 objetos de culto.

**A nocividade dos dípteros era, portanto, conhecida dos antigos médicos-sacerdotes, da mesma maneira que os hemípteros. 
Cidade de Lajes, Santa Catarina

1.1 .1934

Hochverehrter Herr Doctor!

Erlaube mir Ihnen zum neuen Jahr meine herzlichsten Glück- und Segenswünsche zu übersenden. Möge Ihnen Gott im Interesse Ihrer geschätzen Familie und im Interesse der Wissenschaft noch viele Jahre einer segensreichen Tätigkeit verleihen!

Sie schreiben mir in diesen Worten, daß Sie Sich etwas geschwächt fühlen; vielleicht, daß ein zeitweiliges Zurückziehen von aller geistiger Arbeit Ihnen gut tun würde.

Ein Aufenthalt in einem stillen Heim in Teresopolis oder Petropolis während der heißeren Monate, in einer frischen sauerstoffhaltigen Luft bei Genuß einer Fruchtdiät und Leibesübungen verrichten oft Wunder. Traubensaft (ilegível) grape juice (Welsh), wird oft gern von Geschwächten, welche geistig viel tätig sind, unverdünnt (gern) genommen. Unterstützend oft auch zugleich anwendbar Phosphor, preparado de fósforo em forma solúvel de Parke Davis etc.

In der Hoffnung, daß Sie Sich für meine bescheidenen archälogisch-medizinischen Forschungen interessiren düften, erlaube ich mir Foldendes mitzuteilen:

In Grotten und Höhlungen von São Joaquim, mit Erhebungen bis 2100 meter über dem Meeresspiegel, habe ich u[nter] a[nderem] die Idole* von blutsaugenden Dipteren** und Hemipteren aufgefunden, wie auch die Steinmodelle von einfachen [...] Vögeln, ferner zahlreiche lithische Opfergeräte und $\mathrm{zu}$ medizinischen und pharmazeutischen Zwecken benutzte Steingeräte (Messer von verschiedenen Formen, Mörser, Reibsteine $\mathrm{u}[\mathrm{nd}] \mathrm{s}[\mathrm{o}] \mathrm{w}$ [eiter]), welche in der medicina mística oder medicina idólatra nur von den Priesterärzten der ausgestorbenen Tribus, welche [...] waren, angewendet worden sind, aufgefunden. Kein europäisches oder amerikanisches Museum besitzt solche Fundstücke, die für die Geschichte der Medizin von außerordentlichem Werte sind. Einige Fliegemodelle (hämatophage Species, zeigend mit dem Stechrüssel) sind sehr groß.

Ich hege den fromnen Wunsch im Frühjahr eine Reise nach Europa zu machen.

Vielleicht wird es mir möglich sein, im kommenden Monate einen kurzen Ausflug nach Rio de Janeiro unternehmen zu können; bei dieser Gelegenheit werde ich mir erlauben, Ihnen einen Besuch zu machen.

Mit den besten Wünschen für Ihr persönliches Wohlergehen

Ihr sehr ergebener

Geo. C. Bleyer

Notas do autor:

* Meine Sammlung enthält mehr als 250 Kultstücke.

**Die Schädlichkeit der Dipteren ist daher den alten Priesterärzten bekannt gewesen, ebenso der Hemipteren. 


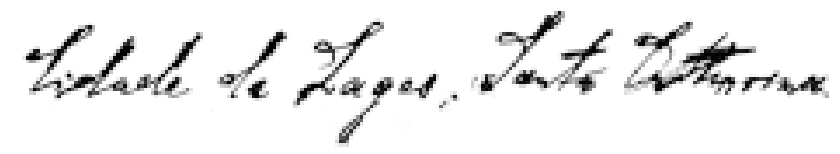$$
\text { - } 1 \text { T193. - }
$$

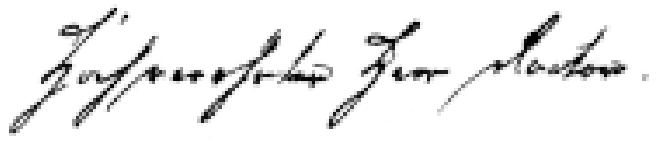

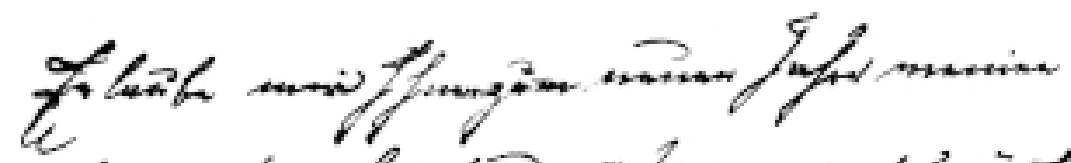

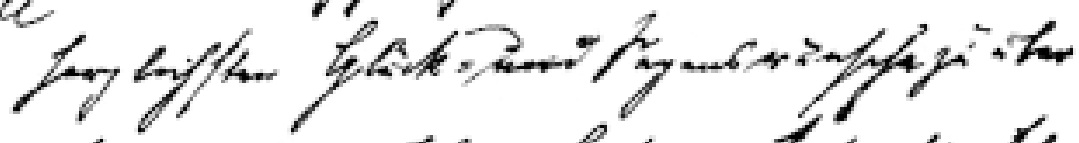

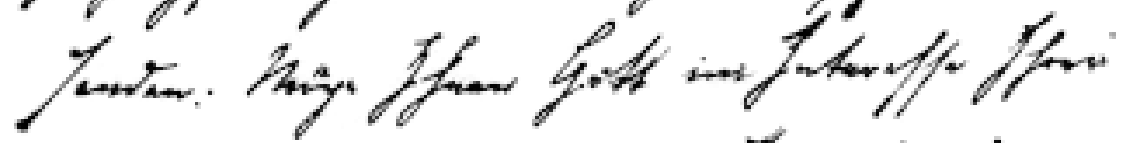

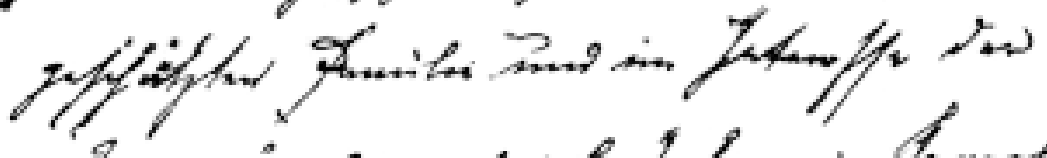

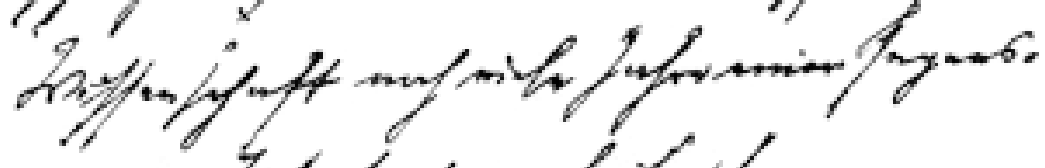

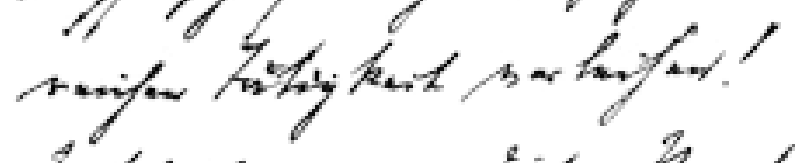

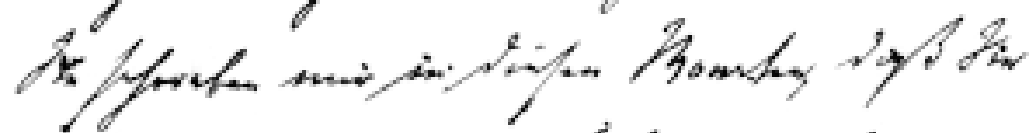

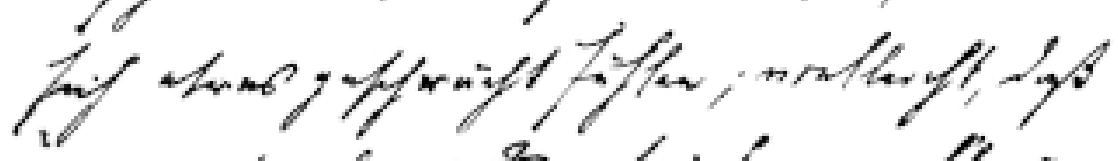

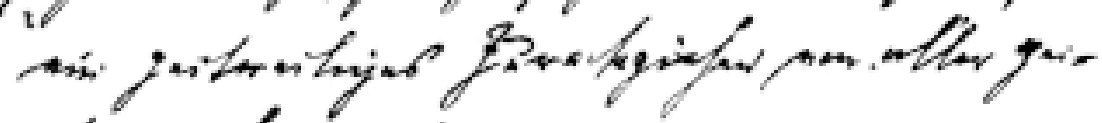

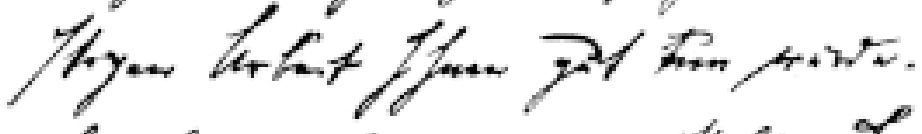

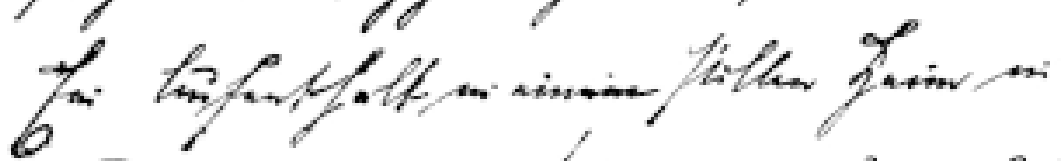

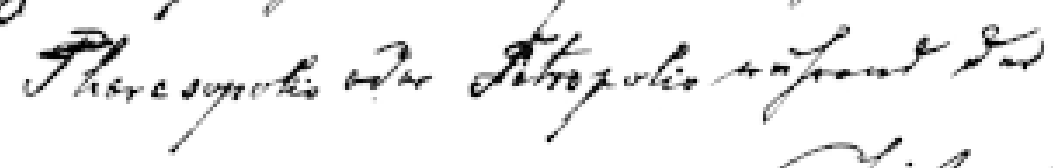
Cripsom 


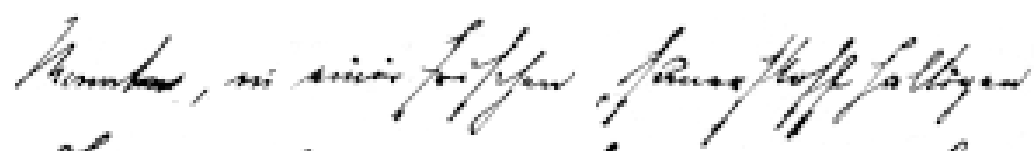

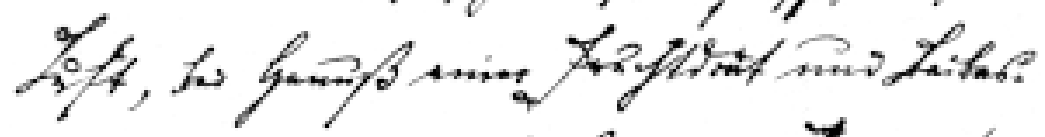

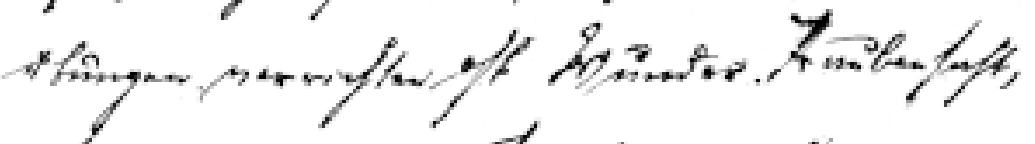

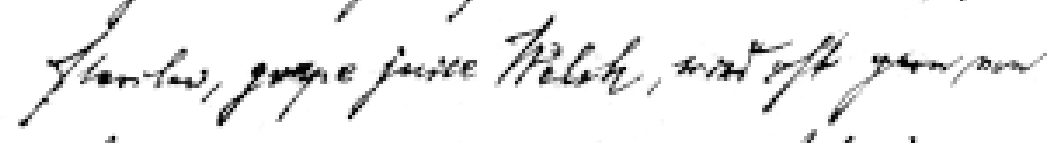

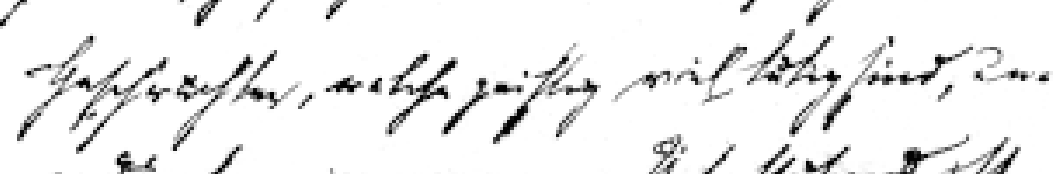

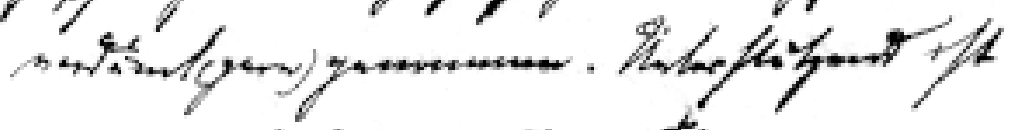

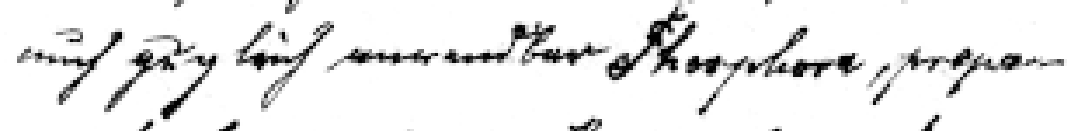

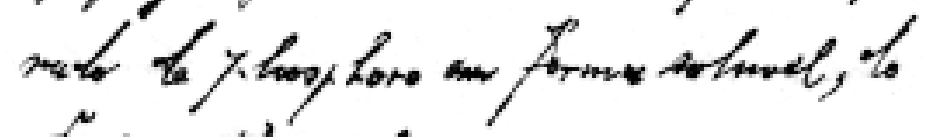
sitre, govidete...

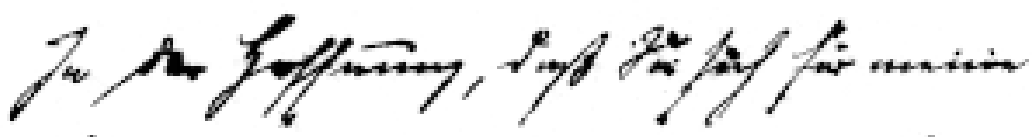

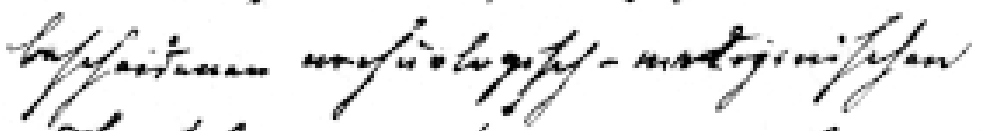

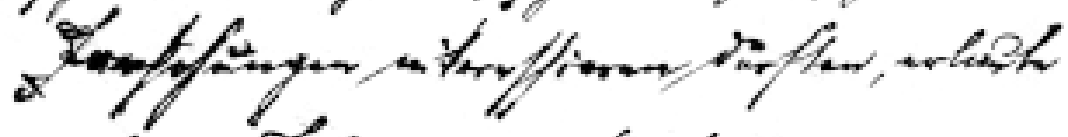

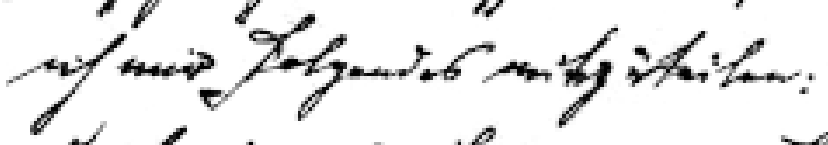

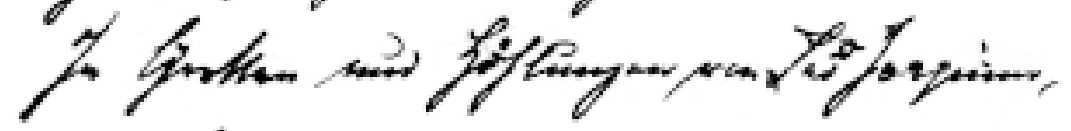

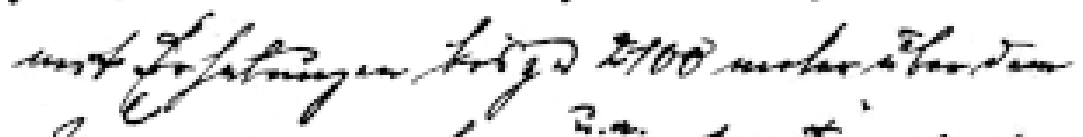

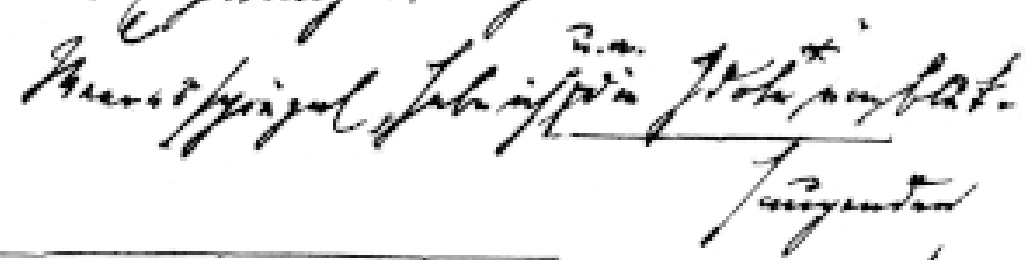

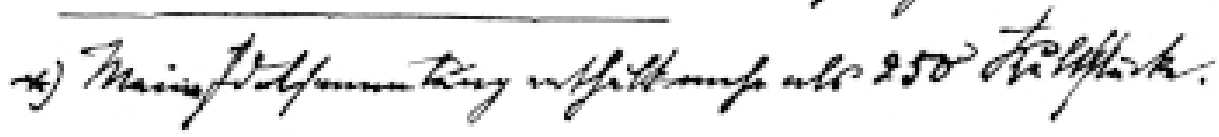




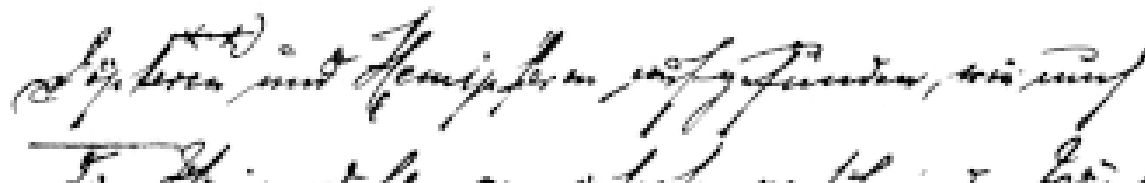

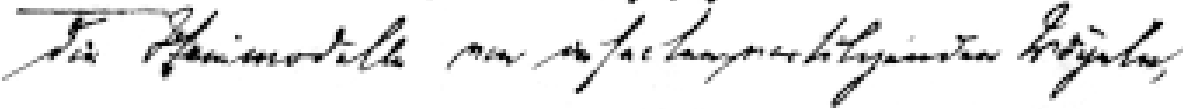

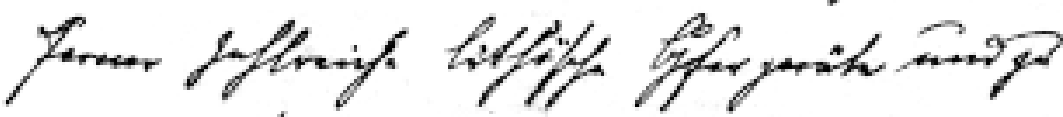

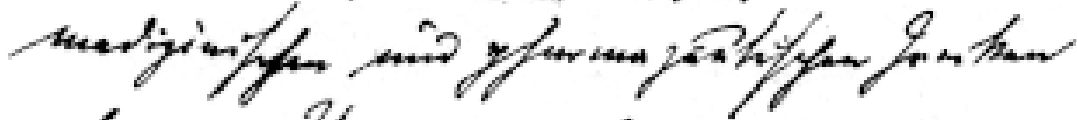

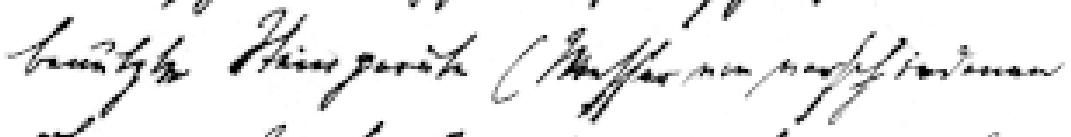

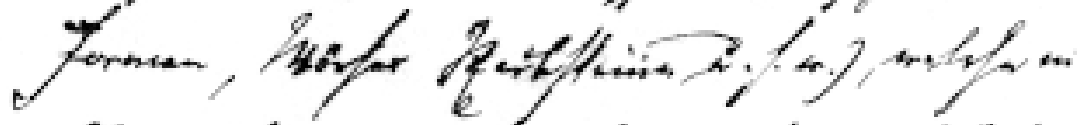

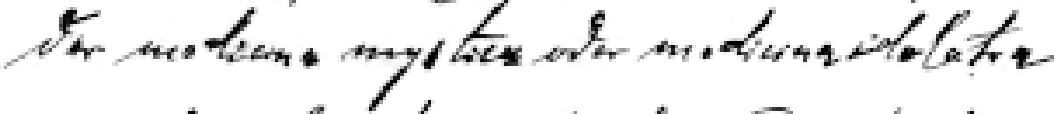

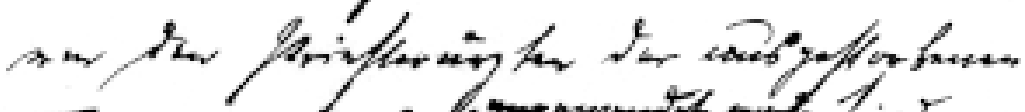

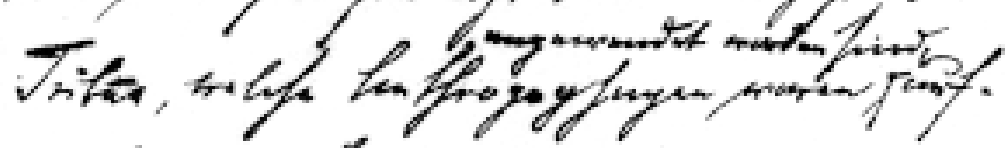

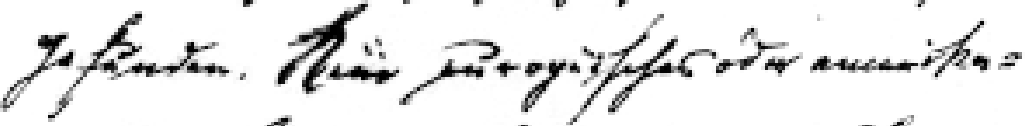

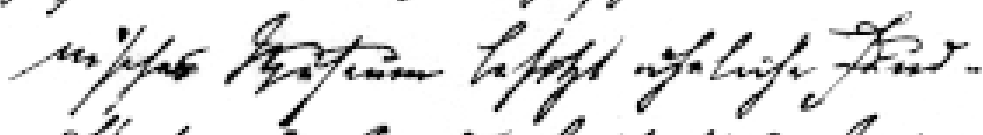

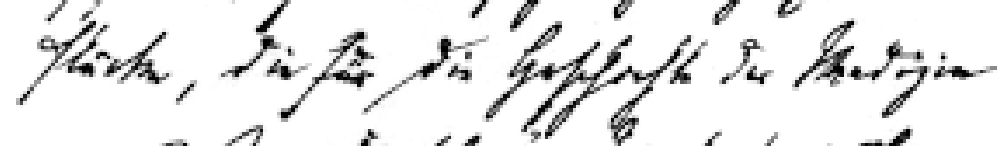

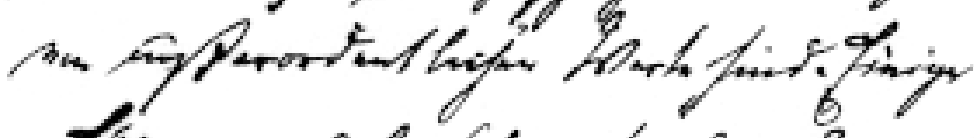

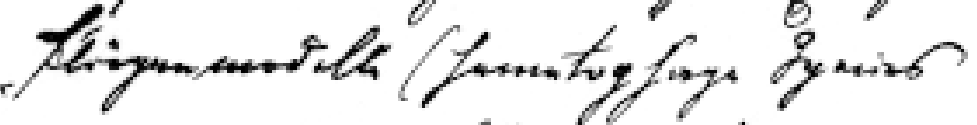

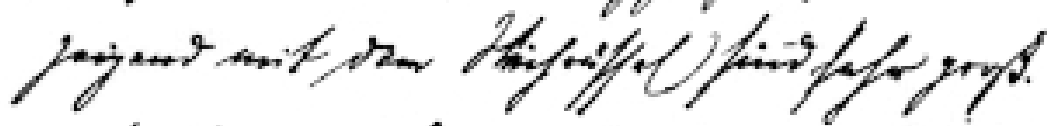

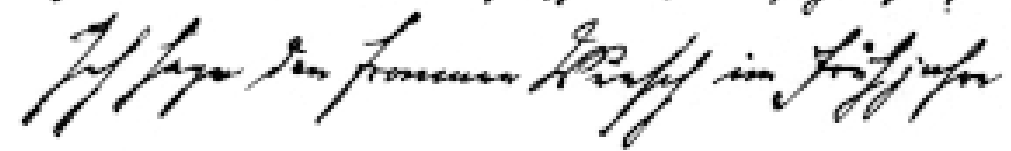

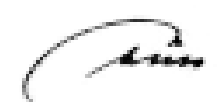

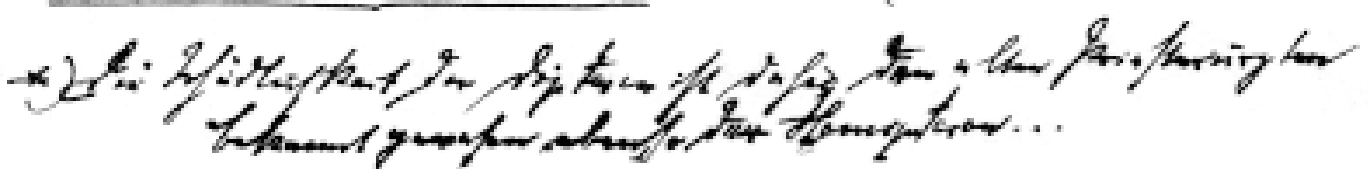




\section{INSTITUTO OSWALDO CRUZ \\ CAIXA POSTAL 926 \\ BRASIL - RIO DE JANEIRO}

Cidade de Lajes, 27 de março de 1934.

Santa Catarina

Rua Corrêa Pinto, 51.

Mui estimado senhor doutor,

Recebi com penhorado agradecimento seu afável escrito de 16 de fevereiro (data do carimbo postal), assim como os fascículos subseqüentes de Natural History, de jan.fev. de 1931, e de set.-out., Nova York, e também Forschungen und Fortschritte, " nº 3, do dia 20 de janeiro de 1933, Berlim. Devolverei estes fascículos na próxima oportunidade.

Em sua carta, o senhor aconselha-me a desistir de viajar para a Europa sob as atuais condições de desordem lá existentes, e oferece-se para colocar-me em contato com o American Museum of Natural History e o Instituto Carnegie.

Tomarei a liberdade de enviar-lhe estes dias um relatório preliminar sobre os resultados das minhas viagens de estudo nos anos de 1931, 1932, 1933, junto com algumas fotografias.

Depois de analisar estas memórias e as fotografias em anexo, peço que tenha a bondade de informar o Instituto Carnegie e o Museu de História Natural em Nova York sobre os resultados da pesquisa, mencionando que o senhor me teria aconselhado a ceder a coleção, certamente singular, aos institutos em questão em troca de honorários equivalentes.

Caso ambos os institutos científicos demonstrem boa vontade, estaria disposto a realizar outras viagens de estudo que fossem de seu interesse.

Mais uma vez e cordialmente agradeço sua nobre oferta, e permaneço, com penhoradas saudações,

seu mui devoto

Geo. Clarke Bleyer.

Junto uma carta com dois recortes dos jornais República e Época de Santa Catarina, que peço ao amigo para devolver-me mais tarde. (N. do A.)

*O título traduzido seria Pesquisas e progressos. (N. do T.) 


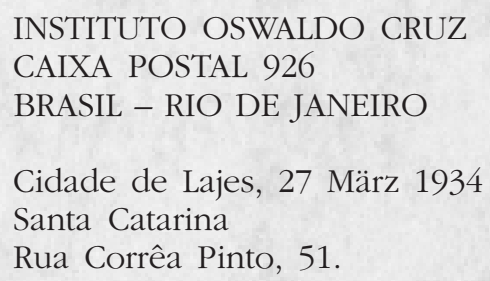

\section{Hochverehrter Herr Doctor,}

Ihr gütiges Schreiben vom 16. Februar (Datum des Poststempels) sowie die beifolgenden Hefte Natural History, Jan.-Feb. 1931 und Sept.-Oct. - New York, sowie Forschungen und Fortschritte, n⿳⺈ 3, vom 20. Januar 1933, Berlin, habe ich mit verbindlichem Dank empfangen. Ich werde diese Hefte mit der nächsten Gelegenheit zurücksenden.

Sie geben mir in Ihrem Briefe den Rat, von einer Europareise abzusehen unter den bestehenden unruhigen Verhältnissen dort und bieten mir Ihre Vermittlung an, um mit dem American Museum of Natural History und dem Carnegie-Institut in Verbindung treten zu können.

Ich werde mir erlauben, Ihnen in diesen Tagen einen vorläufigen Bericht über die Ergebnisse meiner Studienreisen in den Jahren 1931, 1932, 1933 unter Beifügung von einigen Photographien zu übersenden.

Nach Kenntnissnahme dieser Memorias und der beigefügten Lichtbilder bitte ich die grose Güte zu haben, dem Carnegie Institut und dem Naturhistorischen Museum in New York von den Forschungsergebnissen Kunde geben zu wollen, mit der Angabe, dass Sie mir angeraten hätten, den betreffenden Instituten die wohl einzig darstehende Sammlung gegen eine entsprechende Honorierung zu überlassen.

Bei einem entsprechenden Entgegenkommen von beiden diesen wissenschaftlichen Instituten, würde ich bereit sein, im Interesse derselben weitere Studienreisen auszuführen.

Noch einmal für Ihr edles Anerbieten Ihnen herzlich dankend, verbleibe ich mit den verbindlichsten Grüsen

Ihr sehr ergebener

(ass.) Geo. Clarke Bleyer.

Junto uma carta com dois recortes dos jornais República e Época de Santa Catarina, que peço ao amigo para devolver-me mais tarde. (N. do A.) 
Cidade de Lajes, via Bom Retiro

2 de maio de 1934

Santa Catarina

Mui estimado senhor professor,

Sua bondosa missiva de 3 de março do ano em curso recebi em Bom Retiro, no dia 15 de abril.

No intervalo, a contar de hoje, deveria ter chegado em seu prezado endereço o memorial anunciado, as fotografias inclusas e os dois fascículos do American Museum of Natural History, devolvidos, bem como o fascículo alemão sobre a pesquisa e o progresso de Berlim.

Respondendo à sua pergunta se a infecção por Aspergillus já foi encontrada em animais vivos, permiti-me comunicar:

A espécie de Triatoma em cativeiro foi atacada pela doença fúngica, sucumbindo a ele em cerca de oito dias.

No homem [ilegível] micose por Aspergillus pude ver o aparecimento de graves sintomas da doença: pericardite, manifestações pulmonares (abscesso pulmonar), astenia, perturbações gástricas e intestinais, ciática, mesmo miolítica [ilegível].*

Penso poder [ilegível] que também as moscas (Muscidas) morrem de infecção por Aspergillus, não sendo acometidas apenas pela Empusa muscae!

Remeto juntamente com esta dois vidrinhos [contendo em] líquido conservador mosquitos e alguns "carrapatos" do rio São Paulo, um afluente do rio Canoas no município de Lajes [ilegível] das regiões dos campos. Outras pequenas remessas seguirão.

Com distinta e elevada estima e cordiais saudações

Seu mui devoto colega

Geo. Clarke Bleyer

Nota do autor:

*A estes enfermos aconselhei a imediata mudança de habitação. As paredes das habitações infestadas pelo fungo foram caiadas. 
Cidade de Lajes, via Bom Retiro

2. Mai 1934

Santa Catarina

\section{Hochverehrter Herr Professor!}

Ihr gütiges Schreiben vom 3. März d.[ieses] J.[ahres] habe ich in Bom Retiro am $15^{\text {ten }}$ April erhalten.

In der Zwischenzeit, von heute gerechnet, dürfte an Ihre geschätzte Adresse das angekündigte Memorial, die einliegenden Photographien und die zurückgesandten Hefte (2) vom American Museum of Natural History, New York, sowie das deutsche Heft über Forschung und Fortschritte aus Berlin, gelangt sein.

In Beantwortung Ihrer Frage ob die Aspergillus-Infection schon von lebenden Tieren vorgefunden war, erlaube ich mir mitzuteilen:

Die Triatomaspecies wurden in der Gefangenschaft von der Pilz-Krankheit befallen und erlag derselben nach etwa 8 Tagen.

Ich habe beim Menschen [...] Aspergillus-Mycose schwerwiegende Krankheitssymptome auftreten sehen: Pericarditis, Lungenerscheinungen (Lungenabcess), Asthenie, Magen-und Darmstörungen und sciatbische, selbst myolithische Störungen, [ilegível] febril [ilegível].*

Ich glaube (ilegível) zu können, daß auch Fliegen (Musciden) von Aspergillusinfectionen zu Grunde gehen und nicht nur Empusa muscae holen!

Ich übersende beifolgend 2 Gläschen mit [ilegível]. Conservierungs-Flüssigkeit Mosquitos und einige "carrapatos" vom Rio São Paulo, einem Nebenflusse des Rio Canoas, im Municipium von Lages, (ilegível), aus den Camposgebieten. Weitere kleine Sendungen werden nachfolgen.

Mit vorzüglicher Hochachtung

und herzlichen Grüßen

Ihr sehr ergebener College

Geo. Clarke Bleyer

Nota do autor:

*Ich habe solchen Kranken sofortigen Wohnungswechsel angeraten. Die mit dem Pilzen befallenen Wände der Wohnungen wurden mit Kalkmilch bestrichen. 
Cidade de Lajes, 16 de junho de 1934

Santa Catarina

Mui estimado senhor colega,

Recebi sua bondosa missiva de 22 de maio. Lastimo sinceramente que o enfraquecimento de sua vista tenha se acentuado.

Agradeço penhoradamente a gentil remessa de duas separatas de seu mui interessante trabalho 'Zur Kenntnis der brasilianischen Kröten vom genus Bufo'.* O trabalho é primorosamente ilustrado. Permitir-me-ei fazer uma resenha do mesmo numa revista alemã.

Ocupei-me na Alemanha, em tempos passados, especialmente com estudos zoopatológicos. Um trabalho meu que trata pormenorizadamente das serpentes peçonhentas da Europa Central foi citado na grande Enciclopédia Brockhaus, no capítulo 'Serpentes'.

Anexo envio-lhe duas fotografias de Lachesis alternata Neuwied "urutu" e Lachesis coatiara Gomes. As fotografias exibem variedades destas espécies de serpentes peçonhentas que observei na Alta Região de Santa Catarina. Além disso segue com registrado uma pele seca de uma variedade muito interessante de Lachesis alternata que recebi de Painel.

Junto, ainda, à remessa, uma fotografia representando uma queda de neve na região elevada de Santa Catarina. Na Alta Região de Santa Catarina, em altitudes de $2.100 \mathrm{~m}$ sobre o nível do mar a temperatura nas primeiras horas da manhã dos meses de junho e julho pode cair para $-17,5$ a $-18^{\circ} \mathrm{C}$.

Peço que se digne a devolver-me as fotografias das espécies de serpentes peçonhentas, e a pele seca da variedade de Lachesis alternata e a cena hibernal, pois pretendo utilizá-las em trabalhos futuros.

$\mathrm{Na}$ biblioteca do Instituto Oswaldo Cruz encontra-se talvez um volume do $X X$ Congresso de Americanistas, vol. II, Imprensa Nacional, Rio de Janeiro, 1924. O referido volume deve conter um trabalho meu, 'Investigações sobre o homem pré-histórico no Brasil meridional'. Não recebi o volume; talvez V. S. teria a bondade de dar uma olhada no trabalho.

O manuscrito mencionado em sua prezada carta, bem como as fotografias anexas, V. S. pode, junto com a separata (excerto de um acordo preparado pela comissão inglesa), apresentar às instituições científicas com as quais se corresponde sob reserva de válida devolução.

Sua amigável lembrança de "enviar alguém para vistoriar as coisas e eventualmente também visitar os sítios" é bem pensada.

Pessoalmente, sou de descendência teuto-inglesa, tendo, no decorrer do tempo, pouco me correspondido em inglês, daí ter-me distanciado algo da língua inglesa com o passar dos anos. Meus estudos foram influenciados por professores alemães, mas não meu modo de pensar social e meus sentimentos; como filho de uma inglesa nata, nutro certa simpatia pela Inglaterra.

Gostaria de deixar por conta de instituições científicas a avaliação de minha coleção, provavelmente única, resultado de ingentes esforços e muitas crises em Santa Catarina e regiões vizinhas.

Um convite apropriado e transporte pessoal da coleção seriam de meu agrado.

Permito-me indagar se não seria de bom alvitre ceder, como doação ao Instituto Oswaldo Cruz ou à Academia Nacional de Medicina, no Rio de Janeiro, o grande modelo de um mosquito e de uma espécie de mosca hematófaga por mim descobertos.

Como me permiti participar-lhe nestes meses, gostaria de perguntar a W. Junk, em Berlim, se este senhor editor estaria disposto a editar uma monografia minha sobre ídolos de dípteros e hemípteros que descobri. Caso se concretize este desejo, permitame poder dedicar este trabalho a V. S. 
Tanto quanto saiba, nenhum Instituto para a História da Medicina e das Ciências Naturais na Europa possui ídolos de dípteros e hemípteros.

Entre os ídolos antropomórficos descobertos, quase todos procedentes de horizontes do quaternário tardio da época das glaciações, merecem especial destaque: um ídolo de tipo ultrortognato, vários modelos braquicéfalos e mesocéfalos, finalmente duas formas ultradolicocéfalas.

O falecido pesquisador e geólogo prof. dr. Steinmann,** da Universidade de Bonn, especial conhecedor da América do Sul, admite quatro períodos de glaciação que teriam atingido a América do Sul. Infelizmente os trabalhos deste grande sábio quase não se tornaram conhecidos no Brasil, bem como o do prof. dr. E. Werth, 'Grundzüge der Paläanthropologie', *** Berlim, 1921.

Pela hipótese da Atlântida, da lenda da Atlântida, a escola alemã não tinha pendores, nos primeiros anos. Já são outras as opiniões nos últimos anos, devido aos estudos do cruzeiro do Meteor, que permitiu à comissão científica, durante os anos 1925-1927, realizar dez mil sondagens. A literatura sobre a Atlântida é atualmente muito abrangente. A literatura geológica está condensada em:

Ol. Wilkens. 'Atlantis', Geol. Rundschau, Bd. IV, Leipzig e Berlim, 1913.

Além deste, merecem registro as monografias:

L. M. Hosea. 'Atlantis: a statement of the Atlantic theory, respecting aboriginal civilization'. Civ. Quart. Journal of Science, Cincinnati, vol. II, 1875.

M. Clarke, Examination of the legend of Atlantis in reference to protohistoric communication with America. Londres, 1886.

F. Termier, 'L'Atlantide', Bullet. Inst. Océanographique, Monaco, 1913.

T. Peter. Atlantis. Die versunkene Welt.**** Pfllingen, 1922 (dados sobre literatura).

Edgar Daqué, prof. de geologia da Universidade de Munique. Die Atlantissage in Urwelt und Menschbeit***** II. Aufl. 1924, 1928, Munique.

Com os mais sinceros votos pelo seu bem-estar pessoal, Sem mui devoto

Geo. Cl. Bleyer

Notas do tradutor:

*Para o conhecimento dos sapos brasileiros do gênero Bufo.

** Deve ser um lapsus calami; o missivista certamente quis referir-se a Karl von den Steinen (1855-1929).

*** Fundamento da palcantropologia.

**** Atlantis: o mundo submergido.

***** A lenda da Atlântida na pré-história e humanidade, $2^{\underline{a}}$ ed. 
Cidade de Lajes, 16 de junho de 1934

Santa Catarina

Hochverehrter Herr Kollege!

Ihr gütiges Schreiben vom 22. Mai habe ich empfangen. Ich bedauere herzlich, daß Ihre Augenschwäche zugenommen hat.

Für die freundliche Übersendung von 2 Sonderabdrücke Ihrer sehr interessanten Arbeit 'Zur Kenntnis der brasilianischen Kröten vom genus Bufo' danke ich Ihnen verbindlichst. Die Arbeit ist schön illustriert. Ich werde mir erlauben ein Referat darüber in einer deutschen Zeitschrift zu geben.

Ich habe mich in früheren Jahren in Deutschland speciell mit zoopatologischen Studien beschäftigt. Ein Werk von mir, welches in eingreifender Weise die mitteleuropäischen Giftschlangen behandelt, ist im großen Konversations Lexikon von Brockhaus zitiert worden unter dem Kapitel 'Schlangen'.

Anliegend sende ich Ihnen 2 Photographien von Lachesis alternata Neuwied "Urutu" und Lachesis coatiara Gomes. Die Lichtbilder stellen Varietäten dieser Giftschlangenspecies dar, welche ich in der Alta Região von Santa Catarina beobachtet habe. Ferner erfolgt "eingeschrieben" eine getrocknete Haut einer sehr interessanten Varietät von Lachesis alternata, welche ich aus Painel erhalten habe.

Ich füge ferner ein Lichtbild der Sendung bei, welches einen Schneefall in der Hochregion von Santa Catarina darstellt. In der Alta Região von Santa Catarina kann in Höhen von $2100 m$ über den Meeresspiegel gerechnet die Temperatur in den frübesten

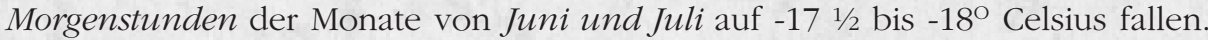

Ich bitte die Lichtbilder der Giftschlangenspecies, die getrocknete Haut der varietas von Lachesis alternata und das Winterbild mir zurücksenden zu wollen, da dieselben für fernere Arbeiten bestimmt sind.

In der Bibliothek des Instituto Oswaldo Cruz findet sich vielleicht ein Band des $X X$ Congresso de Americanistas vol. II. Imprensa Nacional. Rio de Janeiro, 1924. Der betr(effende) Band dürfte eine Arbeit von mir enthalten, 'Investigações sobre o homem pré-histórico no Brasil meridional'. Ich habe den Band nicht empfangen; vielleicht haben Sie die Güte die Arbeit anzusehen.

Das in Ihrem geehrten Schreiben erwähnte Manuskript, sowie die anliegenden Photographien können Sie nebst dem Separatabdrucke (Auszug eines Vertrages, angefertigt von der englischen Kommission) den wissenschaftlichen Instituten, mit welchen Sie korrespondieren, vorlegen unter Vorbehalt späterer, gültiger Rücksendung.

Ihre freundliche Erinnerung "jemand hierher zu schicken um sich die Sachen anzusehen, eventuell auch die Plätze zu besuchen" ist wohl bedacht.

Ich persönlich bin deutsch-englischer Abkunft, habe im Laufe der Zeit wenig englisch korrespondiert, daher bin ich der englischen Sprache etwas entfremdet worden im Laufe der Jahre. Meine Studien sind durch deutsche Professoren beeinflußt worden, aber nicht mein sociales Denken und Fühlen als Sohn einer geborenen Engländerin und eine gewisse Sympathie für England.

Die Einschätzung meiner wohl einzig dastehender Sammlung, das Ergebnis unendlicher Mühe und vieler Krisen in Santa Catarina und den angrenzenden Gebieten, möchte ich den wissenschaftlichen Instituten überlassen.

Eine entsprechende Einladung und persönliche Überführung der Collectionen würde mir angenehm sein.

Ich erlaube mir anzufragen, ob es nicht gut sein würde, das von mir entdeckte große Modell eines Mosquitos und einer hematophagen Fliegenspecies dem Instituto Oswaldo Cruz oder der Academia Nacional de Medicina in Rio de Janeiro als Geschenk zu überlassen.

Wie ich mir erlaubte, Ihnen in diesen Monaten mitzuteilen, möchte ich bei W. Junk in Berlin anfragen, ob dieser Herr Verleger bereit sein würde eine Monographie von 
mir über die entdeckten Idole von Dipteren und Hemipteren in Verlag zu nehmen. Sollte diese Monographie nach Wunsch ausfallen, so erlaube ich mir Ihnen dieses Werk widmen zu dürfen.

Soweit ich unterrrichtet bin, besitzt kein Institut für Geschichte der Medizin und der Naturwissenschaften in Europa Idole von Dipteren und Hemipteren.

Unter den entdeckten anthropomorphen Idolen, welche fast alle aus Horizonten des letzten Quartärs der Vereisungszeit stammen, verdienen speciell Berücksichtigung: 1 Idol von ultraorthognathen Typus, mehrere brachycephale und mesocephale Modelle, endlich 2 ultradolichocephale Formen. Der verstorbene Forscher und Geologe Prof. Dr. Steinmann (sic) von der Universität Bonn, specieller Kenner Südamerikas, nimmt 4 Eiszeitperioden an, welche Südamerika betroffen haben. Leider sind in Brasilien die Arbeiten dieses großen Gelehrten fast gar nicht bekannt geworden, ebenso nicht die von Prof. Dr. [ilegível] 'Gundzüge der Paläanthropologie'. Berlin 1921, Der Atlantishypothese, der Atlantissage, stand die deutsche Schule in früheren Jahren durchaus nicht geneigt gegenüber. In den letzteren Jahren nach den Studien der Meteor-Fahrt, welche während der Jahre 1925-1927 durch die wissenschaftliche Kommission 10.000 Sondierungen ausführen ließ, trat eine andere Meinung ein: Die Literatur über die Atlantis ist zur Zeit eine sehr umfassende. Die geologische Literatur ist zusammengefaßt bei:

Ol. Wilkens, 'Atlantis', Geol. Rundschau Bd. IV Leipzig und Berlin, 1913.

Ferner sind zu vermerken die Monographien:

L. M. Hosea. 'Atlantis: A Statement of the Atlantic Theory, respecting Aboriginal Civilization'. Civ. Quart. Journal of Science, vol. II, Cincinnati, 1875.

M. Clarke. Examination of the legend of Atlantis in reference to protohistoric communication with America. London, 1886.

F. Termier, 'L'Atlantide', Bullet. Inst. Océanographique. Monaco, 1913.

T. Peter. Atlantis. Die versunkene Welt. Pfellingen 1922. (Literaturangaben)

Edgar Daqué. Prof. der Geologie der Universität München. Die Atlantissage in Urwelt und Menschheit. II. Aufl. 1924, 1928, München.

Mit dem herzlichstem Wunsche

für Ihr persönliches Wohlergehen

Ihr sehr ergebener

Geo. Cl. Bleyer. 
Cidade de Lajes, Santa Catarina

31 de janeiro de 1937

Rua Corrêa Pinto, 51

Mui estimado senhor doutor,

Recebi com penhorado agradecimento suas afáveis linhas de 17 de janeiro, bem como duas monografias 'Notas sobre Dicranocercarias brazileiras'.

A espécie gentilmente identificada, Culicoides paraensis e a pequena espécie de mosca com o longo rastro vulnerante, que me chamou a atenção, coletei-as nas margens do pequeno rio São Mateus, na "região da mata" de São Joaquim da Costa da Serra, a $1.400 \mathrm{~m}$ sobre o nível do mar. O tubo de vidro estava enrolado em um pedaço de papel contendo estes dados e o nome do remetente.

Minhas viagens de estudo à "região da mata" de Santa Catarina em elevações até cerca de 2.100m sobre o nível do mar nos anos 1930, 1931, 1932, 1933 forneceram os seguintes resultados interessantes do ponto de vista arqueológico e paleontológico:

1) Descobertas de 14 ídolos de diferentes tipos humanos, alguns em tamanho natural, os quais estão representados na forma e nas condições dos primitivos habitantes extintos. Algumas destas esculturas foram encontradas em horizontes do quaternário tardio em bancos fluviais e de areia postos a seco. Estes ídolos primitivos representam raças da espécie humana que permitem paralelizações com tipos caucásicos, chineses, índicos, ameríndios, egípcios, negróides. Também se encontram nesta coleção alguns restos fósseis de ossos humanos.

2) $O$ achado de numerosas pedras-ídolo zoomorfas, especialmente ornitomorfas, que foram usadas na prática da medicina mística ou de terapia com ídolos por médicossacerdotes fetichistas das tribos do planalto. Estranha é a descoberta de esculturas de esfinges, pedras piramidais, ídolos cordiformes (de pórfiro), finalmente de hemípteros e dípteros (mosquitos, espécies de moscas hematófagas de grandes dimensões, de espécies de rochas raras, especialmente escolhidas).

Pretendo tratar dos ídolos de mosquitos e da espécie de mosca numa monografia especial, com ilustrações segundo tomadas fotográficas. Um editor berlinense, assim espero, aceitará editar o pequeno trabalho.

Permitir-me-ia poder dedicar a V. S. esta monografia.

Meus trabalhos científicos absorvem mais tempo porque uma afecção cardíaca de que sofro exige que me poupe.

Realizo as viagens em certas épocas em ambulância, com instrumentos cirúrgicos e de obstetrícia, exercendo a clínica, para evitar, na medida do possível, maiores despesas.

Talvez me chegue nos próximos meses um convite para fazer uma viagem à Europa! Dar-me-ia grande satisfação poder exibir a um círculo de estudos maior, a uma comissão internacional, o material de estudos certamente singular e coletado com grande sacrifício e mesmo perigos em grotões, cavernas, peraus, bacias lacustres etc.

Com os melhores votos para o seu bem-estar pessoal,

$$
\text { Seu mui devoto, }
$$


Cidade de Lajes, Santa Catarina

31. Januar 1937

Rua Corrêa Pinto, 51

\section{Hochverehrter Herr Doctor!}

Ihre gütigen Zeilen vom 17. Januar a.c., sowie 2 Monographien 'Notas sobre Dicranocercarias brazileiras' habe ich mit verbindlichstem Danke empfangen. Ich lerne immer aus Ihren Schriften!

Die freundlichst bestimmte Species, Culicoides paraensis und die kleine Fliegenart mit dem langen Stechrüsssel, welche mir auffiel, habe ich an den Ufern des kleinen Flusses São Matheus in der "Alta Região" von São Joaquim da Costa da Serra, in 1.400m über dem Meerespiegel gelegen, gesammelt. Der Glastubus war in einen Zettel eingerollt, welcher diese Angaben und den Namen des Absenders enthielt.

Meine Studienreisen in die "Alta Região" von Santa Catarina, mit Erhebungen bis zu 2.100m über dem Meeresspiegel - in den Jahren 1930, 1931, 1932, 1933 haben folgende, vom archäologischen und paläontologischen Standpunkt, interessante Resultate ergeben:

1) Entdeckungen von 14 verschidenen Idolen von Menschentypen, welche zum Teil in natürlicher Größe, in der Form von Zustande von den ausgestorbenen Ureinwohnern dargestellt sind. Einige dieser Sculpturen sind in Horizonten des letzten Quartärs in ausgetrockneten Fluß-und Sandbanken aufgefunden worden. Diese primitiven Idole stellen Menschenracen der Species dar, welche Parallelisierungen mit kaukasischen, chinesischen, indischen, ameroindischen, ägyptischen, negroiden Typen zulassen. - Auch einige wenige fossile Knochenreste von Menschen finden sich in der Sammlung.

2) Das Auffinden von zahlreichen zoomorphen, speciell ornithomorphen Idolsteinen, welche bei der Ausübung der medicina mystica oder Idoltherapie von Seiten der Fetischenpriesterärzten der Stämme des Hochlandes Anwendung gefunden haben. Merkwürdig ist die Entdeckung von Sculpturen von Sphingen, Pyramidensteine, Herzidolen (aus Porphyr), endlich von Hemipteren und Dipteren (Mosquitos, hematophagen Fliegenarten von großen Dimensionen, aus besonders ausgewählten, seltenen Steinarten...

Die Idole der Mosquitos und der Fliegenspecies beabsichtige ich in einer besonderen Monographie zu besprechen unter Beifügung von Illustrationen nach photographischen Aufnamen. Ein Berliner Verleger, so hoffe ich, wird das kleine Werk in Verlag nehmen. Ich würde mir erlauben, Ihnen diese Monographie widmen zu dürfen.

Meine wissenschaftlichen Arbeiten nehmen längere Zeit in Anspruch, da ich am Herzen leide und mir Schonung auferlegen muß...

Die Reisen habe ich ausgeführt zu bestimmten Zeiten, unter Mitmachung einer Ambulanz, von chirurgischen und geburtshilflichen Instrumenten, die Klinik ausübend, um nach Möglichkeit größere Kosten zu vermeiden.

Vielleicht wird mir in kommenden Monaten eine Einladung zu Teil eine Europareise zu machen: es würde mir eine große Freude sein, das wohl einzig dastehende Studienmaterial, welches ich unter großen Mühen und selbst Gefahren in Grotten, Höhlen und Uferschluchten, Seebecken u(nd) s(o) w(eiter) gesammelt habe, einem größeren Studienkreise, einer internationalen Kommission vorlegen zu können.

Mit den besten Wünschen für Ihr persönliches Wohlergehen Ihr sehr ergebener 